Review

\title{
Bio-Oil: The Next-Generation Source of Chemicals
}

\author{
Henrique Machado $^{1}\left(\mathbb{D}\right.$, Ana F. Cristino $^{2}(\mathbb{D})$, Sofia Orišková ${ }^{1}\left(\mathbb{D}\right.$ and Rui Galhano dos Santos ${ }^{1, *(D)}$ \\ 1 Centre for Natural Resources and the Environment (CERENA), Instituto Superior Técnico, \\ Universidade de Lisboa, Av. Rovisco Pais, 1049-001 Lisboa, Portugal; henrimac97@gmail.com (H.M.); \\ sofia.oriskova@tecnico.ulisboa.pt (S.O.) \\ 2 Centro de Química Estrutural, Institute of Molecular Sciences and Departamento de Química e Bioquímica, \\ Faculdade de Ciências, Universidade de Lisboa, Campo Grande, 1749-016 Lisboa, Portugal; afcristino@fc.ul.pt \\ * Correspondence: rui.galhano@ist.utl.pt
}

\begin{abstract}
Bio-oil, although rich in chemical species, is primarily used as fuel oil, due to its greater calorific power when compared to the biomass from which it is made. The incomplete understanding of how to explore its chemical potential as a source of value-added chemicals and, therefore, a supply of intermediary chemical species is due to the diverse composition of bio-oil. Being biomass-based, making it subject to composition changes, bio-oil is obtained via different processes, the two most common being fast pyrolysis and hydrothermal liquefaction. Different methods result in different bio-oil compositions even from the same original biomass. Understanding which biomass source and process results in a particular chemical makeup is of interest to those concerned with the refinement or direct application in chemical reactions of bio-oil. This paper presents a summary of published bio-oil production methods, origin biomass, and the resulting composition.
\end{abstract}

Keywords: bio-oil; hydrothermal liquefaction; pyrolysis; biomass

check for updates

Citation: Machado, H.; Cristino, A.F.; Orišková, S.; Galhano dos Santos, R. Bio-Oil: The Next-Generation Source of Chemicals. Reactions 2022, 3 ,

118-137. https://doi.org/10.3390/ reactions3010009

Academic Editors: Anker Degn Jensen and Dmitry Yu. Murzin

Received: 3 December 2021

Accepted: 26 January 2022

Published: 28 January 2022

Publisher's Note: MDPI stays neutral with regard to jurisdictional claims in published maps and institutional affiliations.

Copyright: () 2022 by the authors Licensee MDPI, Basel, Switzerland. This article is an open access article distributed under the terms and conditions of the Creative Commons Attribution (CC BY) license (https:// creativecommons.org/licenses/by/ $4.0 /)$.

\section{Introduction}

As the dialogue concerning climate change and carbon neutrality deepens, the human reliance on fossil fuels is greatly criticized. At the same time, climate change creates new concerns, which obligate us, as an inventive and adaptive species, to find strategies to battle adversity. This also presents a necessity to think seriously about how human activities influence the environment. Keeping these issues in mind while designing these new strategies is the key to carbon neutrality.

Frequent and severe forest fires are only preventable if there is a commitment to cleaning and caring for forested areas. During this process, significant volumes of organic matter are collected, which could be employed in new applications, such as using them as raw material, thus turning waste into an asset. Bio-oil production is an appealing concept for generating fuel from lignocellulosic biomatter, or other biomass, while also reducing dependence on fossil fuels. Recent approaches to reducing dependency on fossil fuels, such as biorefineries, may have lignocellulosic-rich biomass as a by-product [1], further increasing bio-oil feedstock availability. Bio-oil has a higher heating value when compared to its feedstock, and when burned, it can potentially generate a lower amount of greenhouse gas when compared to fossil fuels [2]. Therefore, its most studied application is still as a burning fuel, but other applications are emerging due to its composition, as is the case of foams and resins [3]. The latter applications emphasize the potential of bio-oil as a source of value-added chemicals.

Many sources of feedstocks have been studied [4-6] along with their applications as fuels, chemical sources, or raw materials in direct applications. A great deal of recent research has investigated ways to improve bio-oil performance as fuels: the use of catalysts, feedstock pre-treatment, and bio-oil upgrading to enrich the resulting bio-oil in hydrocarbons, therefore making it less abundant in $\mathrm{N}$ - and O-containing compounds [7]. However, 
the presence of these compounds also highlights the possibility of having bio-oils as a source of chemical species or for direct application in chemical industries.

This work aims to give a brief introduction to bio-oil as a chemical source, serving as a referral point of the recent research on bio-oil production while commenting on the path previous research on the subject has taken.

\section{Thermochemical Processes}

Bio-oil is obtained via an array of thermochemical processes. The most common of these processes are pyrolysis and hydrothermal liquefaction [6-16]. These processes convert a given feedstock into bio-oil, biochar, and gas, with their composition dependent on feedstock type, pre-treatment, process, operating conditions, and later upgrading [5,8,9].

Pyrolysis processes are characterized by processing temperatures as high as $600{ }^{\circ} \mathrm{C}[10,11]$, shorter reaction times, and the necessity to dry feedstock before processing. Hydrothermal liquefaction eliminates the need for feedstock drying and utilizes water as a solvent at lower temperatures, but may require the application of pressures from 5 to $20 \mathrm{MPa}$ [12]. Thermal liquefaction usually refers to processes, such as hydrothermal liquefaction, but utilizes organic solvents such as ethanol and acetone. In all of these processes, catalysts are frequently employed to modulate resulting bio-oil composition and improve the yield of total bio-oil or specific components [10].

Some authors also distinguish between light and heavy bio-oil, both making up for the entire bio-oil fraction extracted from a biomass source. The liquid fraction resulting from the thermochemical process is called light oil, and it is richer in phenols, ketones, and aldehydes than its source material. The solid portion is further extracted with an organic solvent, and a heavy oil is therefore obtained. It has a higher viscosity, associated with a higher content of longer hydrocarbons [13]. Two phases may be present when the water content in bio-oil exceeds a certain wt.\%, thus creating the so-called water-soluble and organic phases [14].

Most researchers choose pyrolysis processes over hydrothermal and thermal liquefaction, which only represent about $30 \%$ of recent studies. In addition to resulting in different bio-oil compositions, their associated costs are also different. One study, which compared the economic viability of bio-oil production from palm residues, found pyrolysis to have almost double the cost of a hydrothermal process [15]. The authors also concluded that achieving higher bio-oil yields would reduce costs more than improving the energetic efficiency of the applied process. Research on producing bio-oil in the last 5 years has also mostly focused on fuel making, about $70 \%$, when compared to other applications, as seen in Figure 1.

DISTRIBUTION OF STUDIED THERMOCHEMICAL PROCESSES

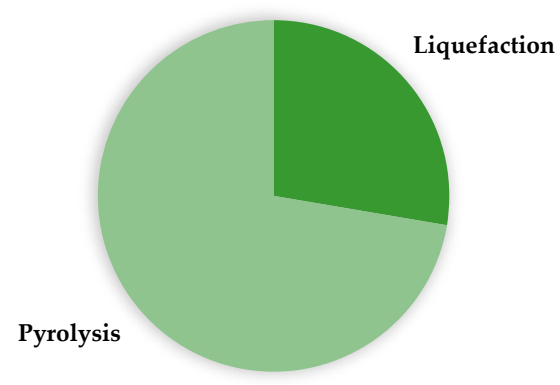

END APPLICATION

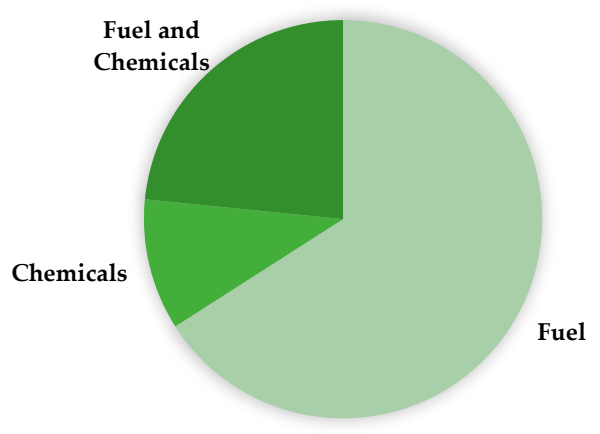

Figure 1. Distribution of thermochemical processes and end application from bio-oil production research in the last 5 years (according to a search made in Web of Science).

Previous literature has already observed that pyrolysis bio-oil research frequently uses some sort of high-volume and low-value agricultural residue (rice husk or straw, wheat 
straw or some form of oil palm residue) as feedstock [5]. This is still somewhat true today, as many of the works presented in this paper still make use of one of these feedstocks. Research that focuses on other, more uncommon biomasses mostly focus on fuel production and thus are often absent in information useful for other applications.

In Tables 1 and 2, an overview is given on the most recent studies involving the thermo-chemical liquefaction and pyrolysis of several feedstocks to produce bio-oil. The application and conversion yields (\%) are presented for all studies.

Table 1. Summary of thermochemical liquefaction bio-oil references.

\begin{tabular}{|c|c|c|c|c|}
\hline Feedstock & $\begin{array}{c}\text { Thermochemical } \\
\text { Process }\end{array}$ & Application & Yield (\%) & Ref. \\
\hline Amphiroa fragilissima & HTL & Fuel & 29 & [16] \\
\hline Animal manure & HTL & Fuel and Chemicals & 31 & [17] \\
\hline Cellulose & HTL & Fuel & - & [18] \\
\hline Corn stover & HTL & Fuel & 29 & [19] \\
\hline Corn straw & HTL & Fuel and Chemicals & 8 & [20] \\
\hline Cow dung & HTL & Fuel and Chemicals & 57 & [21] \\
\hline Dunaliella $s p$ & HTL & Fuel & 13 & [22] \\
\hline Eucalyptus & $\mathrm{TL}$ & Chemicals & 30 & [23] \\
\hline Eucalyptus globulus & TL & Fuel & 96 & [24] \\
\hline Hay & HTL & Fuel & - & [18] \\
\hline Karanja press seed cake & TL & Fuel & 99 & [25] \\
\hline $\begin{array}{c}\text { Lemon Peel and Spirulina } \\
\text { Platensis }\end{array}$ & HTL & Fuel & 26 & [26] \\
\hline Lignin & TL & Fuel and Chemicals & 63 & [27] \\
\hline Miscanthus & HTL & Fuel & 26 & [28] \\
\hline Nostoc ellipsosporum & HTL & Chemicals & 25 & [29] \\
\hline Oak wood & HTL & Fuel & - & [18] \\
\hline Palm kernel shell & HTL & Fuel and Chemicals & 16 & [30] \\
\hline Peanut straw & HTL & Fuel and Chemicals & 15 & [20] \\
\hline Pinewood shaves & $\mathrm{TL}$ & Fuel & 99 & [31] \\
\hline Pinus ponderosa & HTL & Fuel & 16 & [1] \\
\hline Poplar & HTL & Fuel & 20 & [32] \\
\hline Potato peels & $\mathrm{TL}$ & Fuel and Chemicals & 80 & [33] \\
\hline Rhodococcus opacus & HTL & Fuel & 27 & [34] \\
\hline Rice husk & HTL & Fuel and Chemicals & 60 & [21] \\
\hline Rice straw & CHTL & Chemicals & - & [35] \\
\hline Rice straw & CHTL & Fuel & 67 & [36] \\
\hline Rice straw & HTL & Chemicals & 48 & [35] \\
\hline Rice straw & HTL & Fuel & 30 & [13] \\
\hline Rice straw & TL & Fuel & 23 & [37] \\
\hline Rice straw & HTL & Fuel and Chemicals & 15 & [20] \\
\hline $\begin{array}{l}\text { Rice Straw and municipal } \\
\text { sewage sludge }\end{array}$ & $\mathrm{TL}$ & Fuel & 32 & [37] \\
\hline Scenedesmus obliquus & HTL & Fuel & 40 & [38] \\
\hline Sewage sludge & HTL & Fuel & 25 & [28] \\
\hline Soybean straw & HTL & Fuel and Chemicals & 16 & [20] \\
\hline Spirulina & $\mathrm{TL}$ & Fuel & 50 & [39] \\
\hline Spirulina & HTL & Fuel & 33 & [28] \\
\hline Spirulina platensis, pre-treated & HTL & Fuel & 50 & [40] \\
\hline Switchgrass & $\mathrm{TL}$ & Fuel and Chemicals & 40 & [41] \\
\hline Walnut shell & HTL & Fuel & - & [18] \\
\hline Woodchips & $\mathrm{TL}$ & Fuel & 27 & [37] \\
\hline $\begin{array}{l}\text { Woodchips and municipal } \\
\text { sewage sludge }\end{array}$ & $\mathrm{TL}$ & Fuel & 32 & [37] \\
\hline
\end{tabular}


Table 2. Summary of pyrolysis bio-oil references.

\begin{tabular}{|c|c|c|c|c|}
\hline Feedstock & Thermochemical Process & Application & Yield (\%) & Ref. \\
\hline Acacia cincinnata & IP & Fuel & 53 & [42] \\
\hline Acacia holosericea & IP & Fuel & 47 & [42] \\
\hline Acacia mangium & $\mathrm{CP}$ & Fuel & 45 & [43] \\
\hline Acacia sawdust & $\mathrm{P}$ & Fuel & $29-45$ & [44] \\
\hline Amphiroa fragilissima & $\mathrm{P}$ & Fuel & 33 & [16] \\
\hline Bamboo & $\mathrm{P}$ & Fuel & 47 & [45] \\
\hline Bamboo residues & $\mathrm{P}$ & Fuel & 45 & [46] \\
\hline Brewery residue & Co-P & Fuel and Chemicals & 56 & [47] \\
\hline Camellia oleifera shell & $\mathrm{MP}$ & Fuel & 27 & [48] \\
\hline Cassava peel & $\mathrm{P}$ & Chemicals & - & [49] \\
\hline Cellulose & $\mathrm{FP}$ & Chemicals & $61-85$ & [50] \\
\hline Chlorella vulgaris & $\mathrm{CP}$ & Fuel & 20 & [51] \\
\hline Chlorella vulgaris & $\mathrm{FP}$ & Fuel and Chemicals & - & [52] \\
\hline Coconut fibers & $\mathrm{P}$ & Chemicals & - & [49] \\
\hline Coconut shells & $\mathrm{P}$ & Fuel & 50 & [46] \\
\hline Coffee silverskin & $\mathrm{P}$ & Chemicals & - & [49] \\
\hline Corncobs & $\mathrm{P}$ & Fuel & 44 & [46] \\
\hline Corrugated cardboard & $\mathrm{P}$ & Fuel & 47 & [53] \\
\hline Cotton seed & $\mathrm{FP}$ & Fuel & & [54] \\
\hline Cotton seeds & $\mathrm{P}$ & Chemicals & - & [49] \\
\hline Cotton stalk & $\mathrm{CP}$ & Fuel & $53-56$ & [55] \\
\hline Crambe seeds & $\mathrm{P}$ & Chemicals & - & [49] \\
\hline Crofton weed & $\mathrm{P}$ & Fuel and Chemicals & 29 & [56] \\
\hline Duckweed & $\mathrm{P}$ & Chemicals & - & [49] \\
\hline Enteromorpha clathrate & $\mathrm{P}$ & Fuel & - & [57] \\
\hline Eucalyptus grandis & $\mathrm{CP}$ & Fuel & $12-29$ & [58] \\
\hline Eucalyptus sawdust & $\mathrm{P}$ & Chemicals & - & [49] \\
\hline $\begin{array}{c}\text { Extracted marine chlorella sp. } \\
\text { residue }\end{array}$ & $\mathrm{MP}$ & Fuel & 46 & [59] \\
\hline Food waste & $\mathrm{MP}$ & Fuel and Chemicals & 30 & [60] \\
\hline Forest residue & Co-P & Fuel & 23 & [61] \\
\hline Giant miscanthus & FP & Fuel & 50 & [62] \\
\hline Hardwood & $\mathrm{P}$ & Fuel & 55 & [63] \\
\hline Hemicellulose & $\mathrm{FP}$ & Chemicals & $34-56$ & [50] \\
\hline Imperata cylindrica & $\mathrm{P}$ & Fuel and Chemicals & 37 & [64] \\
\hline Lactuca scariola & $\mathrm{CP}$ & Fuel & 34 & [65] \\
\hline Larch sawdust & $\mathrm{CP}$ & Chemicals & - & [66] \\
\hline Lemon myrtle & $\mathrm{P}$ & Fuel and Chemicals & 39 & [67] \\
\hline Lignin & FP & Fuel & 30 & [68] \\
\hline Lignin & $\mathrm{FP}$ & Chemicals & $27-55$ & [50] \\
\hline Mahua seed & $\mathrm{P}$ & Fuel & 50 & [69] \\
\hline Mango seeds & $\mathrm{P}$ & Chemicals & - & [49] \\
\hline Moso bamboo & $\mathrm{MP}$ & Fuel & 30 & [70] \\
\hline Municipal solid waste & $\mathrm{IP}$ & Chemicals & 11 & [71] \\
\hline Napier grass & $\mathrm{FP}$ & Fuel & 33 & [72] \\
\hline Neem bark & $\mathrm{P}$ & Fuel & 38 & [45] \\
\hline Oily sludge and rice husk & Co-P & Fuel & 72 & [73] \\
\hline Olive pomace & $\mathrm{MP}$ & Fuel and Chemicals & 30 & [74] \\
\hline $\begin{array}{l}\text { Olive pruning residue, olea } \\
\text { europea }\end{array}$ & MP & Chemicals & 40 & [75] \\
\hline Organosolv lignin & $\mathrm{P}$ & Fuel & 30 & [76] \\
\hline Palm empty fruit bunch & $\mathrm{FP}$ & Fuel & 64 & [77] \\
\hline Palm empty fruit bunch & $\mathrm{MP}$ & Chemicals & 38 & [78] \\
\hline Palm kernel shell and sludge & Co-P & Fuel & 41 & [79] \\
\hline Palm shell & $\mathrm{P}$ & Fuel & 73 & [80] \\
\hline Peach cores & $\mathrm{P}$ & Chemicals & - & [49] \\
\hline Peanut shell & $\mathrm{P}$ & Chemicals & - & [49] \\
\hline
\end{tabular}


Table 2. Cont.

\begin{tabular}{|c|c|c|c|c|}
\hline Feedstock & Thermochemical Process & Application & Yield (\%) & Ref. \\
\hline Pine & $\mathrm{P}$ & Fuel & 48 & [81] \\
\hline Pine needles & $\mathrm{CP}$ & Fuel and Chemicals & 51 & [82] \\
\hline Pineapple leaves & $\mathrm{P}$ & Chemicals & - & [49] \\
\hline Pinewood sawdust & FCo-P & Fuel & 72 & [83] \\
\hline Populus wood & $\mathrm{FP}$ & Fuel and Chemicals & 63 & {$[84]$} \\
\hline Posidonia oceanica & $\mathrm{CP}$ & Fuel and Chemicals & 51 & [85] \\
\hline Red cedar & $\mathrm{FP}$ & Fuel & 53 & {$[86]$} \\
\hline Rice husk & $\mathrm{P}$ & Chemicals & - & [49] \\
\hline Rice husk & $\mathrm{P}$ & Fuel & 15 & [87] \\
\hline Rice husk & CFP & Fuel & 47 & [88] \\
\hline Rice husk & $\mathrm{FP}$ & Fuel & 48 & [89] \\
\hline Rice husk & $\mathrm{P}$ & Fuel & 42 & [45] \\
\hline Rice husk & $\mathrm{P}$ & Fuel and Chemicals & 75 & [90] \\
\hline Rice straw & $\mathrm{MP}$ & Fuel & 32 & [48] \\
\hline Rice straw & $\mathrm{P}$ & Fuel & 33 & {$[91]$} \\
\hline Rice straw & $\mathrm{MP}$ & Fuel and Chemicals & 30 & [92] \\
\hline Sawdust & $\mathrm{FP}$ & Fuel & 60 & [62] \\
\hline $\begin{array}{l}\text { Scrap tire and pinewood } \\
\text { sawdust }\end{array}$ & FCo-P & Fuel & 55 & [83] \\
\hline $\begin{array}{c}\text { Scrap tire and sugarcane } \\
\text { bagasse }\end{array}$ & Co-P & Fuel & 50 & [93] \\
\hline Sewage sludge & MP & Fuel and Chemicals & 75 & [94] \\
\hline Softwood & $\mathrm{P}$ & Fuel & 50 & [76] \\
\hline Softwood & $\mathrm{FP}$ & Fuel & 31 & [95] \\
\hline Spent coffee grounds & $\mathrm{P}$ & Chemicals & - & [49] \\
\hline Spruce wood & FP & Fuel and Chemicals & 65 & [84] \\
\hline Sugarcane bagasse & $\mathrm{P}$ & Fuel & 39 & [45] \\
\hline Sugarcane bagasse & $\mathrm{CP}$ & Fuel & 30 & [96] \\
\hline Sugarcane bagasse & $\mathrm{P}$ & Chemicals & - & [49] \\
\hline Sugarcane bagasse & $\mathrm{P}$ & Fuel & 53 & [91] \\
\hline Sweet lime & $\mathrm{P}$ & Fuel & 28 & [97] \\
\hline Sweet sorghum bagasse & FP & Chemicals & 50 & [98] \\
\hline Switchgrass & $\mathrm{P}$ & Fuel & 46 & [81] \\
\hline Switchgrass and pine & $\mathrm{P}$ & Fuel & 45 & [81] \\
\hline Tobacco seeds & $\mathrm{P}$ & Chemicals & $14-47$ & [49] \\
\hline Tobacco wastes & $\mathrm{P}$ & Fuel and Chemicals & 67 & [99] \\
\hline Tomato peel & $\mathrm{P}$ & Fuel & 40 & [100] \\
\hline Tulip tree & $\mathrm{CP}$ & Fuel & 49 & [101] \\
\hline Waste cooking oil & MP & Fuel & 40 & [102] \\
\hline Wheat stalk & $\mathrm{FP}$ & Fuel & - & [103] \\
\hline Wheat straw & $\mathrm{P}$ & Fuel & 37 & [91] \\
\hline Wheat straw & $\mathrm{P}$ & Fuel & 60 & [104] \\
\hline Wheat straw & $\mathrm{P}$ & Fuel & 42 & [105] \\
\hline Coffee silverskin & $\mathrm{P}$ & Chemicals & 15 & [106] \\
\hline Gelidium sesquipedale & $\mathrm{P}$ & Fuel and Chemicals & 24 & [107] \\
\hline
\end{tabular}

$\mathrm{IP}$-intermediate pyrolysis; $\mathrm{CP}$ —catalytic pyrolysis; $\mathrm{P}$-pyrolysis; Co-P—co-pyrolysis; $\mathrm{MP}$-microwave pyrolysis, FP-fast pyrolysis.

\section{Thermochemical Conversion Routes of Biomass}

Feedstock cellulose, hemicellulose, and lignin contents affect the resulting bio-oil chemical composition as they individually contribute to different chemical groups, as can be seen in Table 3. Cellulose and hemicellulose thermochemical conversion mostly results in anhydrous sugars, furans, pyrans, light oxygenated compounds, and some phenolic species. Lignin, in turn, produces high quantities of phenolic compounds, such as methoxyphenols, aldehydes, ketones, and light oxygenated species [50]. 
Table 3. Summary of fast pyrolysis products of cellulose, hemicellulose, and lignin. Adapted from [50].

\begin{tabular}{cccccc}
\hline & \multicolumn{3}{c}{ Contents (\%) } \\
\cline { 2 - 6 } Feedstock & Phenols & $\begin{array}{c}\text { Phenolic } \\
\text { Aldehydes and } \\
\text { Ketones }\end{array}$ & Furans & Anhydro-Sugars & $\begin{array}{c}\text { Other O } \\
\text { Containing }\end{array}$ \\
\hline Cellulose & - & - & $11-17$ & $40-77$ & $0-40$ \\
Hemicellulose & $0-13$ & - & $26-58$ & $6-28$ & $2-67$ \\
Lignin & $44-65$ & $25-55$ & - & - & $1-10$ \\
\hline
\end{tabular}

This is due to the depolymerization of cellulose, hemicellulose, and lignin, with following dehydration, reduction, retro-aldol, decarboxylation and deamination reactions [88,108]. At the end stages of the reaction, oxidation, isomerization, esterification, and aromatization may occur. During pyrolysis, these reactions occur in the gas phase, while during hydrothermal and thermal liquefaction, they take place in the solvent.

A few authors have tried to relate lignocellulosic contents to final bio-oil compositions $[18,49,109-111]$, but correlations seem insufficient to accurately predict the bio-oil composition for a given feedstock [50], with some arriving at the conclusion that even ash content has an influence on final bio-oil compositions [112].

Cellulose affects the thermochemical conversion of lignin and vice versa [10]. Combining various feedstock sources can result in interesting outcomes, either by improving bio-oil yield or by causing changes in composition, as demonstrated in the work of Leng et al. [37]. Authors were able to increase the contents of specific chemical groups beyond the amount obtained from the isolated feedstocks and decrease others through a combination of lignocellulosic matter in varying proportions. However, others who tried similar approaches did not achieve the same results [93] — this further highlights how biomass and bio-oil composition have a more complex than simple correlation.

Nevertheless, it could be considered that since lignin decomposes at higher temperatures than cellulose and hemicellulose, increases in processing temperatures result in higher yields of bio-oil as opposed to bio-char yield. Bio-oil portions of phenols, ketones, and aldehydes should also increase, as they are lignin conversion products.

Since biomass such as algae [113], bacteria [114] and food waste [115] are instead rich in proteins and lipids rather than cellulose and lignin, their thermochemical conversion products are mostly N-containing compounds and fatty acids. In Figure 2, a general proposal of the chemical groups that derive from biomass is shown.

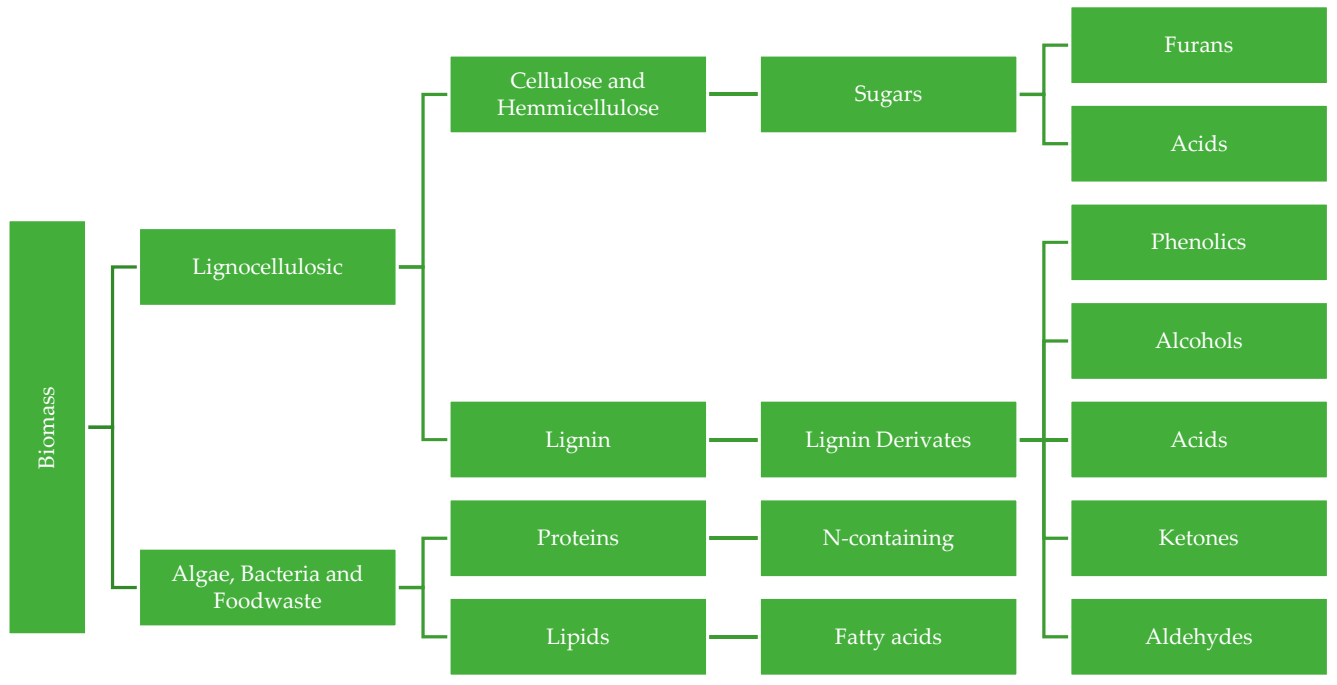

Figure 2. Proposed chemical groups derived from biomass components. 


\section{Bio-Oil Chemical Composition and Characteristics}

\subsection{General Traits}

Since bio-oil is a product of lignocellulosic thermal conversion, it constitutes a blend of phenols, aldehydes, ketones, furans, alcohols, acids, hydrocarbons, and many others depending on its feedstock $[10,116]$. Its production process, operating conditions, pretreatments of the feedstock [117], or later upgrading techniques [118] also determine the final composition. Table 4 summarizes typical bio-oil attributes, even though recent studies have managed to achieve better-performing traits with increased heating values and $\mathrm{pH}$ and lower water content and viscosity.

Table 4. Summary of typical bio-oil characteristics. Adapted from [119,120].

\begin{tabular}{cccccccccc}
\hline & \multicolumn{1}{c}{ Elemental Composition wt $\%$} \\
\hline \multirow{2}{*}{ Viscosity } & $\begin{array}{c}\text { Relative } \\
\text { Density }\end{array}$ & pH & $\begin{array}{c}\text { Water } \\
\text { Content }\end{array}$ & Heating Value & O & N & C & H & Ash \\
\hline $25-100 \mathrm{cP}$ & $1.1-1.2$ & $2.8-4$ & $15-30 \mathrm{wt} \%$ & $16-26 \mathrm{MJ} / \mathrm{kg}$ & $27-40$ & $0.05-1$ & $55-64$ & $5-8$ & $0.03-0.3 \%$ \\
\hline
\end{tabular}

Although naturally rich in $\mathrm{N}$ - and $\mathrm{O}$-containing compounds, such values translate into thermal instability and a tendency toward corrosiveness. These traits, together with high viscosity and water content, are suboptimal for fuel applications, and thus, many seek to reduce the amount of $\mathrm{N}$ and $\mathrm{O}$ compounds in bio-oil, further improving its behavior and efficiency as fuel.

Many of the works in Tables 1 and 2 compare the achieved bio-oil composition with mineral fuels or are concerned with improving thermal capabilities. Naturally, this is of interest if the goal is its application in fuel, cracking, or fractioning processes (such as with petroleum). Nevertheless, bio-oil has proven to have other interesting applications due to its phenolic compounds, for example. In addition, increasing bio-oil fuel performance involves catalysts and upgrading techniques, increasing the production cost. Moreover, currently, bio-oil production as a fuel substitute is not considered to be economically attractive enough to pose a serious alternative to fossil fuels [59].

Biomass is thermochemically converted into bio-oils of varying compositions with the high dispersity of chemical species. If we could control the bio-oil chemical composition, we would be able to manufacture bio-oil with a direct application in mind or as an intermediary to chemicals. This could be achieved via the careful selection of feedstocks, operation conditions and the employment of catalysts. High concentrations of specific chemical species are present in some bio-oils, as shown in Tables 5 and 6. Though, for the same feedstock, some chemical groups are presented in ranges, demonstrating how authors managed to achieve different chemical makeups through variations in methodology alone. 
Table 5. Summary of approximate bio-oil compositions from works in Table 1 or others of interest.

\begin{tabular}{|c|c|c|c|c|c|c|c|c|c|c|c|}
\hline \multirow{2}{*}{ Feedstock } & \multirow{2}{*}{ Process } & \multicolumn{10}{|c|}{ Contents (\%) } \\
\hline & & Phenols & Esters & Ketones & Acids & Alcohols & Hydrocarbons & Furans & N-Containing & Aldehydes & Ref. \\
\hline Cellulose & HTL & 13 & - & 21 & 2 & - & - & 1 & - & 24 & [18] \\
\hline Corn straw & HTL & 53 & - & 21 & 4 & 1 & 1 & - & 3 & 1 & [20] \\
\hline Nostoc ellipsosporum & HTL & 1 & 3 & - & 8 & - & 25 & 8 & - & 4 & [29] \\
\hline Oak wood & HTL & 38 & - & 14 & 5 & - & - & - & - & 14 & [18] \\
\hline $\begin{array}{l}\text { Palm empty fruit } \\
\text { bunch }\end{array}$ & HTL & 7 & - & 16 & - & - & - & - & - & - & [121] \\
\hline Palm mesocarp fiber & HTL & 89 & - & 5 & - & - & - & - & - & - & [121] \\
\hline Peanut straw & HTL & 28 & & 26 & 8 & 1 & 4 & & 6 & 1 & [20] \\
\hline Pinus ponderosa & HTL & 30 & 4 & - & 5 & - & - & 1 & - & - & [1] \\
\hline Rice straw & CHTL & 46 & 19 & 7 & 1 & 3 & 11 & 2 & - & - & {$[35]$} \\
\hline Rice straw & CHTL & $28-44$ & - & $2-12$ & - & $5-11$ & - & - & $5-16$ & - & [36] \\
\hline Rice straw & HTL & 45 & 13 & 16 & 7 & 5 & 0.5 & 1 & - & 0.1 & [35] \\
\hline Rice straw & HTL & 25 & - & 9 & 6 & 9 & - & - & - & - & [36] \\
\hline Rice straw & HTL & $46-70$ & - & $10-42$ & - & $1-42$ & - & - & - & $1-2$ & [122] \\
\hline Rice straw & $\begin{array}{l}\text { HTL, heavy } \\
\text { oil }\end{array}$ & $0-2$ & - & 4-9 & $0-0.5$ & $0-13$ & $13-28$ & - & 9-18 & - & [13] \\
\hline Rice straw & $\begin{array}{l}\text { HTL, light } \\
\text { oil }\end{array}$ & $14-39$ & $0-7$ & $8-24$ & $2-7$ & $0-16$ & $0-12$ & $0-6$ & $0-6$ & $3-23$ & [13] \\
\hline Rice straw & $\begin{array}{l}\text { CHTL, heavy } \\
\text { oil }\end{array}$ & $0-2$ & - & $5-7$ & $8-27$ & $7-11$ & $16-36$ & - & $11-26$ & - & [13] \\
\hline Rice straw & $\begin{array}{l}\text { CHTL, light } \\
\text { oil }\end{array}$ & $14-41$ & $0-1$ & $9-25$ & $3-8$ & $3-27$ & $2-13$ & $0-2$ & $0-0.5$ & $1-19$ & [13] \\
\hline Rice straw & HTL & 34 & - & 35 & 1 & 1 & 5 & - & 4 & 2 & [20] \\
\hline Soybean straw & HTL & 29 & - & 50 & 1 & - & 6 & - & 8 & 2 & [20] \\
\hline Spirulina platensis & HTL & 6 & 20 & 2 & 1 & - & 7 & 5 & 37 & - & [40] \\
\hline Walnut shell & HTL & 50 & 1 & 4 & 2 & - & - & - & - & 4 & [18] \\
\hline
\end{tabular}

HTL—hydrothermal liquefaction; CHTL—catalytic hydrothermal liquefaction. 
Table 6. Summary of approximate bio-oil compositions from works in Table 2 or others of interest.

\begin{tabular}{|c|c|c|c|c|c|c|c|c|c|c|c|c|}
\hline \multirow[b]{2}{*}{ Feedstock } & \multirow[b]{2}{*}{ Process } & \multicolumn{11}{|c|}{ Contents (\%) } \\
\hline & & Phenols & Esters & Ketones & Acids & Alcohols & Hydrocarbons & Furans & $\begin{array}{l}\text { Anhydro- } \\
\text { Sugar }\end{array}$ & $\begin{array}{c}\mathrm{N}- \\
\text { Containing }\end{array}$ & Aldehydes & Author \\
\hline Acacia mangium & $\mathrm{CP}$ & 35 & - & 18 & - & 13 & - & 4 & 45 & - & 5 & {$[43]$} \\
\hline Bamboo residues & $\mathrm{P}$ & 37 & - & 17 & - & 18 & - & 20 & - & - & 3 & [46] \\
\hline Cellulose & FP & - & - & - & - & - & - & $11-17$ & $40-77$ & - & - & [50] \\
\hline $\begin{array}{l}\text { Chlorella sp. } \\
\text { residue }\end{array}$ & $\mathrm{P}$ & 18 & 18 & 3 & 12 & 6 & 0.5 & 6 & 2 & 30 & - & [59] \\
\hline Coconut shells & $\mathrm{P}$ & 43 & - & 4 & - & 22 & - & 1 & - & - & 6 & [46] \\
\hline Crofton weed & $\mathrm{P}$ & 13 & 15 & - & 6 & 13 & 2 & 11 & - & - & 28 & [56] \\
\hline Hemicellulose & FP & $0-13$ & - & - & - & - & - & $26-58$ & $6-28$ & - & - & [50] \\
\hline Lignin & $\mathrm{FP}$ & $44-65$ & - & - & - & - & - & - & - & - & - & [50] \\
\hline $\begin{array}{l}\text { Palm empty fruit } \\
\text { bunch }\end{array}$ & MFP & $59-73$ & $11-16$ & $12-19$ & & $8-9$ & - & - & - & $3-8$ & - & {$[78]$} \\
\hline $\begin{array}{l}\text { Palm empty fruit } \\
\text { bunch }\end{array}$ & $\mathrm{P}$ & 12 & - & - & 88 & - & 1 & - & - & - & - & [123] \\
\hline Palm kernel shell & FP & $17-25$ & - & - & $19-28$ & - & - & - & - & - & - & [124] \\
\hline Palm kernel shell & MP & 71 & - & - & - & - & - & - & - & - & - & [125] \\
\hline Palm shell & $\mathrm{P}$ & 22 & - & - & 4 & 3 & - & 2 & - & 47 & 1 & [126] \\
\hline Pinewood sawdust & CO-FP & 11 & - & 7 & 6 & 4 & - & 6 & 5 & 1 & 8 & [83] \\
\hline $\begin{array}{l}\text { Polyhydroxyalkanoate } \\
\text { bacteria }\end{array}$ & $\mathrm{P}$ & 18 & - & 10 & 46 & & - & - & - & 21 & - & [114] \\
\hline Rice husk & $\mathrm{P}$ & 8 & - & 6 & 0.2 & 1 & - & 1 & - & - & 1 & [87] \\
\hline Rice straw & $\mathrm{P}$ & 8 & 4 & 25 & - & 28 & - & 17 & 5 & - & - & [91] \\
\hline $\begin{array}{c}\text { Scrap tire and } \\
\text { sugarcane bagasse }\end{array}$ & CO-P & 52 & - & 12 & 11 & 11 & - & - & - & - & 5 & [93] \\
\hline Sugarcane bagasse & $\mathrm{P}$ & 20 & - & - & 15 & 4 & - & - & - & - & 40 & [123] \\
\hline Sugarcane bagasse & $\mathrm{P}$ & 23 & 3 & 16 & - & - & - & 23 & 24 & - & - & [91] \\
\hline Wheat stalk & $\mathrm{FP}$ & $26-27$ & - & 8 & $10-11$ & - & - & - & - & - & - & [103] \\
\hline Wheat straw & $\mathrm{P}$ & 19 & 12 & 30 & - & 27 & - & 7 & 0.3 & - & - & [91] \\
\hline
\end{tabular}


The following sections further describe the main compounds found in bio-oils from works in Tables 5 and 6, according to their chemical group.

\subsection{Phenols}

Phenolic compounds frequently make up the major portion of bio-oils since they derive from lignin. Phenol, guaiacol, cresol, eugenol, catechol, and syringol are commonly the principal phenolic compounds found in bio-oil $[127,128]$. The pyrolysis of bio-oil from palm waste enables the waste to be successfully converted in bio-oil (34\% yield) with phenol-derived compounds of up to $90 \%$ [121], with some containing phenol as the major entity of the group, up to $65 \%$ ( $25 \%$ bio-oil yield) [125].

\subsection{Ketones and Aldehydes}

Bio-oil from sugarcane bagasse (53\% yield) can contain a $40 \%$ fraction of aldehydes [123]. One study on pretreated sunflower seed hulls even attained $97 \%$ furfural content in bio-oil (33\% yield) [129]. Nevertheless, aldehydes usually make up less than below $25 \%$, often in the form of furfural, glycolaldehyde, and hydroxyacetaldehyde [127,128].

Similarly to aldehydes, ketones are often below the $25 \%$ range, but there are reports of higher concentrations, such as in the case of a rice husk bio-oil (50\% yield) with $40 \%$ ketones content [122]. One of the most common ketones is hydroxyacetone [127,128].

\subsection{Acids}

Acetic acid, propanoic acid, levulinic acid, and fatty acids are acids that are commonly present in the highest proportions in bio-oil $[127,128]$. The recuperation of acetic acid from bio-oil is described by some as a viable approach to bio-oil valorization besides fuel [130], as is the case for glycolic and formic acids [131].

Bio-oil from olive pomace (30\% yield), for example, can be made up of $72 \%$ acetic acid alone [74], followed by others such as moso bamboo bio-oil (30\% yield), with $47 \%$ acetic acid [70], bacteria bio-oil (28\% yield), with $41 \%$ acetic acid [114], or even Napier grass bio oil (33\% yield), with 35\% acetic acid [72]. Acids are normally present in lower levels than phenols, ketones, or aldehydes.

\subsection{Sugars and Alcohols}

The most common alcohols and sugars are acetol, ethylene glycol, levoglucosan, and cellobiosan $[127,128]$. Although they are mostly found in lower concentrations, it is possible to produce bio-oils with somewhat higher amounts of alcohol or sugar. For instance, bio-oil produced from corrugated cardboard (47\% yield) achieved $20 \%$ levoglucosan content [53], while there are also reports of alcohol levels around 40\% (50\% bio-oil yield) [122] and 30\% (33\% bio-oil yield) [91].

\subsection{N-Containing}

$\mathrm{N}$-containing compounds typically have a lower concentration in bio-oil, often on a residual level, but when they are present, they can be in somewhat high amounts, mostly when bio-oil is obtained from feedstock with elevated contents of proteins. In bio-oil made from palm residue, amines made up almost $50 \%$ of the total content, $47 \%$ alone corresponding to trimethylamine [126]. Other bio-oils with elevated levels of $\mathrm{N}$-containing compounds can also be found [40,59], such as the case of food waste bio-oil with $20 \%$ 2-ethoxyethylamine and 20\% methyl phosphine [60]. The bio-oil yield from these sources is below $50 \%$.

\section{Applications of Bio-Oil as Chemical Source and Its Refinement Strategies}

While recent works point towards bio-oil as a chemical source of ketones, aldehydes, and acids, most applications are related to the high contents of phenolic compounds. Biooils rich in phenols and sugars tend to cross-polymerize over time [132,133], especially 
if they contain polymerization promoters in their composition (e.g., furfural) and acids catalysts such as acetic acid [134].

In fact, there are reports of bio-oil being used to produce phenol-formaldehyde resins and adhesives [124,135-138]. Bio-oil is considered suitable by many for phenolic resins due to its high reactivity and low molecular weight [139] and is therefore regarded as a renewable alternative [140]. Sweetgum hardwood bio-oil, for example, was utilized as a partial raw material to produce phenol-formaldehyde resin adhesives with greater bonding strength than ordinary phenol-formaldehyde resin [139].

Other works describe the utilization of bio-oil to produce polyols from which polyurethane foams are later achieved with increased tensile strength and thermal stability and higher biodegradability [141-143]. Bio-oil in bitumen applications is also reported to possibly increase bitumen performance and reduced binder consumption [3,116,144-149].

Many of these more straightforward applications may sometimes still require the preparation of bio-oil to remove water and lower weight acids [136], for example. As sources of various chemical entities, the refinement of bio-oil and separation processes should be applied in other industries in need of platform chemicals. Conveniently, processes such as supercritical extraction, membrane separations, solid-liquid extractions, solvent extraction, and others are described in existing reviews and works [127,150-152], as is also the case for the adequate analytic characterization of bio-oil for chemical applications [153-156].

However, methodologies such as feedstock pre-treatments, the use of catalysts, or process enhancements often enable bio-oils to be produced with improved selectivity.

Pretreatments for feedstock are also described and often result in bio-oils with more defined chemical distribution [129,157-159], which could in turn reduce or even eliminate the need to refine or treat bio-oil after production.

Similarly, other authors obtained more than one bio-oil fraction with different chemical makeups. One study, which describes the hydrothermal liquefaction of rice husks, attained two bio-oil fractions, light and heavy. The light fraction was rich in phenols, ketones, alcohols, and aldehydes, and the heavy presented up to $36 \%$ hydrocarbon content but also $26 \%$ of N-compounds. Nevertheless, the light and heavy fractions may be deemed suitable for use in the extraction of chemicals and for fuel applications, respectively [13].

Others managed to change pyrolysis-derived bio-oil composition through condensation parameters alone, decreasing water content and increasing phenol and furfural presence [128], or through the separation of bio-oil into different condensing temperature fractions, so-called fractional condensation [90,160-162]. Fractional condensation allows for the separation of different chemically enriched fractions according to their vapor pressure [152], offering the possibility to efficiently utilize the entire biomass liquefaction condensate. Typically, lignin-derived species and sugars are obtained in higher-temperature fractions, as opposed to acids and water, which are abundant in lower-temperature fractions [163].

Heavier fractions with low water content and corrosiveness display higher heating value, thus making them suitable for fuel applications. Mid-range fractions are rich in phenol and aldehyde species, making them suitable for the partial substitution of phenolic raw material in resol resins and the production of polyurethane foams. The recovery of acids such as acetic acid is possible for the lighter, water- and acid-rich fractions [164].

With similar outcomes, there is also the possibility to generate bio-oil fractions through pyrolysis with two or more steps [165], supercritical $\mathrm{CO}_{2}$ fractioning [166-168], or separations using ionic liquids $[169,170]$.

\section{Final Remarks and Prospects}

Both pyrolysis and thermal liquefactions present advantages and disadvantages according to the selected feedstock and desired application. Pyrolysis may require previous drying of biomass in the case of less dry feedstocks, but it is possible to employ the processes of fractional condensation later, thus obtaining fractions enriched with different 
chemical species and therefore suitable for different applications. This may be an adequate choice for lignocellulosic biomass, which is usually less humid and produces bio-oils with various chemical groups.

On the other hand, hydrothermal liquefactions may be more suitable for feedstocks with elevated water content such as food processing waste, algae, bacteria, or even sewage sludges. Since hydrothermal processes do not produce condensates, it is not possible to employ fractional condensation methods, and as such, the latter separation methods may be necessary. However, non-lignocellulosic feedstock bio-oils are usually rich in either $\mathrm{N}$-containing species or fatty acids and their esters, which may in turn require less complex separation methods.

Naturally, it is expected that that cellulose- and hemicellulose-rich feedstocks produce bio-oils abundant in sugars and their derivates, and in turn, lignin-rich biomass produces bio-oil with higher contents of phenols, ketones, and aldehydes. However, there seems to be no direct correlation between feedstock lignocellulosic composition and resulting bio-oil chemical makeup, as the last is also heavily dependent on the chosen process, its conditions, the employment of catalysts, and is even dependent on the chemical interactions between species during thermal processing.

Bio-oil production is mostly approached as an alternative fuel allowing for the reduction in petroleum dependency while making use of organic waste, also making it a strong waste management candidate for biomatter. However, its often-high amounts of oxygenated compounds push the need to employ upgrading methods [171,172]. This need places bio-oil fuel production above the viable economic cost, and this is why much recent research focusses on the co-processing of bio-oil and fossil fuel as a cost-effective way to transition to biofuels made from bio-oil [151,173-175]. It should be noted that bio-oil economics and viability for fuel purposes are usually measured against fossil fuels that, besides being an already established industry, are often subject to government subsidies.

Besides its undeniable potential as biofuel, bio-oil chemical makeup could be so valuable that it is difficult to understand why so little research has been carried out for other applications when compared to that of biofuel, but this is probably due to governments pushing the need to reduce greenhouse gas emissions in fuel and transportation sectors.

While it was previously thought that the extraction of chemicals from bio-oil was not advantageous due to low specific chemical contents and the high economic cost of separation processes [116], recent works suggest that it is possible to obtain more componentspecific bio-oils. Additionally, even the co-processing of bio-oil may still require bio-oil to be upgraded [176], thus raising the question whether separation processes are that disadvantageous when compared to upgrading.

It has been shown that bio-oil composition could be somewhat modified and enhanced through the selection of feedstock, the employment of catalysts or pretreatments, or changes in processing parameters. The utilization of bio-oil in resin, foam, and bitumen making also resulted in some better performing products. An application of bio-oil as a successful insecticidal product is also described.

Additionally, via some thermochemical processes, it is also possible to obtain two bio-oil fractions, the light and heavy. The light fraction, abundant in oxygenated compounds, could certainly be further separated and value-added chemicals could be obtained, or it could be utilized as raw material in resin making, allowing bio-based polymers to be produced. The heavy fraction is in turn rich in hydrocarbons and low in the problematic oxygenated compounds and water, thus making it suitable for fuel oil and possibly requiring less upgrading, thus lowering costs. Other similar approaches of bio-oil fractioning through the control of condenser temperatures or two-step conversions were also able to separate bio-oil into fractions with different compositions.

Phenolic species are often the most sought after in the chemical valuing of bio-oil due to their natural high concentration. However, works on bio-oil from feedstock such as algae and food waste can also deliver considerable concentrations of other chemicals species while utilizing waste that is often regarded as less chemically interesting. 
Bio-oil is currently produced by a handful of companies or joint ventures such as Ensyn, Chevron, Vyterra, BTG-Bioliquids, Green fuel Nordic Oy, and Secil Group either for fuel application or later co-processing at refineries such as Petrobras in Brazil, also for fuel purposes.

The production of bio-oil-based chemicals appears to still be under investigation by many of above-mentioned companies, with some even open for collaboration on the issue. Nevertheless, Kerry has been refining bio-oil from Ensyn for many years to produce food flavors and aromatics. The absence of bio-oil-based platform chemical industries somewhat mirrors the current state of research on the matter, but the interest of bio-oil producing companies on the subject further confirms the value that resides in it.

Additionally, while either bio-oil fuel or chemicals cannot, at present, be considered economically viable, such an evaluation may not prove true in the near future, as these assessments are tied to the time and place in which they are made. As mentioned, they are also compared to fossil resources and industries that are often still subject to large subsidies as opposed to bio-oils or other fossil alternatives.

There is an overall feeling that bio-oil for fuel and bio-oil for chemical applications are both disconnected faces of the same problem that could greatly benefit from each other if kept in mind together. Indeed, bio-oil appears to be a great alternative to fossil fuels, but it is possible that, as is the case for petrol, it could offer much more and thus become a well-footed competitor to fossil fuels while also acting as a serious form of waste management.

Author Contributions: Conceptualization of the review, A.F.C. and R.G.d.S.; writing-original draft preparation, H.M. and S.O.; writing — review and editing, H.M., A.F.C., S.O. and R.G.d.S.; supervision, A.F.C. and R.G.d.S. All authors have read and agreed to the published version of the manuscript.

Funding: This work was partially supported through FCT strategic funding of Centro de Química Estrutural (FCT-UIDB/00100/2020) and CERENA (FCT-UIDB/04028/2020).

Data Availability Statement: Not applicable.

Acknowledgments: The authors would like to acknowledge the support of Centro de Química Estrutural (Strategic Project FCT-UIDB/00100/2020) and CERENA (Strategic Project FCT-UIDB/04028/2020).

Conflicts of Interest: The authors declare no conflict of interest.

\section{References}

1. Jaswal, R.; Shende, A.; Nan, W.; Amar, V.; Shende, R. Hydrothermal liquefaction and photocatalytic reforming of pinewood (Pinus ponderosa)-derived acid hydrolysis residue for hydrogen and bio-oil production. Energy Fuels 2019, 33, 6454-6462. [CrossRef]

2. Shan Ahamed, T.; Anto, S.; Mathimani, T.; Brindhadevi, K.; Pugazhendhi, A. Upgrading of bio-oil from thermochemical conversion of various biomass-Mechanism, challenges and opportunities. Fuel 2021, 287, 119329. [CrossRef]

3. Hu, X.; Gholizadeh, M. Progress of the applications of bio-oil. Renew. Sustain. Energy Rev. 2020, 134, 110124. [CrossRef]

4. Ahmad, S.F.K.; Ali, U.F.M.; Isa, K.M. Compilation of liquefaction and pyrolysis method used for bio-oil production from various biomass: A review. Environ. Eng. Res. 2020, 25, 18-28. [CrossRef]

5. Guedes, R.E.; Luna, A.S.; Torres, A.R. Operating parameters for bio-oil production in biomass pyrolysis: A review. J. Anal. Appl. Pyrolysis 2018, 129, 134-149. [CrossRef]

6. Mohan, D.; Pittman, C.U.; Steele, P.H. Pyrolysis of Wood/Biomass for Bio-oil: A Critical Review. Energy Fuels 2006, 20, 848-889. [CrossRef]

7. Schmitt, N.; Apfelbacher, A.; Jäger, N.; Daschner, R.; Stenzel, F.; Hornung, A. Thermo-chemical conversion of biomass and upgrading to biofuel: The Thermo-Catalytic Reforming process-A review. Biofuels Bioprod. Biorefining 2019, 13, 822-837. [CrossRef]

8. Bridgwater, A.V. Review of fast pyrolysis of biomass and product upgrading. Biomass Bioenergy 2012, 38, 68-94. [CrossRef]

9. Bridgwater, A.V. Upgrading biomass fast pyrolysis liquids. Environ. Prog. 2012, 31, 261-268. [CrossRef]

10. Chen, X.; Che, Q.; Li, S.; Liu, Z.; Yang, H.; Chen, Y.; Wang, X.; Shao, J.; Chen, H. Recent developments in lignocellulosic biomass catalytic fast pyrolysis: Strategies for the optimization of bio-oil quality and yield. Fuel Process. Technol. 2019, 196, 106180. [CrossRef]

11. Venderbosch, R.H. Fast Pyrolysis. In Thermochemical Processing of Biomass: Conversion into Fuels, Chemicals and Power; John Wiley \& Sons: Hoboken, NJ, USA, 2019; pp. 175-206. 
12. Xiu, S.; Shahbazi, A. Bio-oil production and upgrading research: A review. Renew. Sustain. Energy Rev. 2012, 16, 4406-4414. [CrossRef]

13. Younas, R.; Hao, S.; Zhang, L.; Zhang, S. Hydrothermal liquefaction of rice straw with NiO nanocatalyst for bio-oil production. Renew. Energy 2017, 113, 532-545. [CrossRef]

14. Valle, B.; Remiro, A.; García-Gómez, N.; Gayubo, A.G.; Bilbao, J. Recent research progress on bio-oil conversion into bio-fuels and raw chemicals: A review. J. Chem. Technol. Biotechnol. 2019, 94, 670-689. [CrossRef]

15. Chan, Y.H.; Tan, R.R.; Yusup, S.; Lam, H.L.; Quitain, A.T. Comparative life cycle assessment (LCA) of bio-oil production from fast pyrolysis and hydrothermal liquefaction of oil palm empty fruit bunch (EFB). Clean Technol. Environ. Policy 2016, 18, 1759-1768. [CrossRef]

16. Arun, J.; Gopinath, K.P.; SundarRajan, P.S.; Malolan, R.; AjaySrinivaasan, P. Hydrothermal liquefaction and pyrolysis of Amphiroa fragilissima biomass: Comparative study on oxygen content and storage stability parameters of bio-oil. Bioresour. Technol. Rep. 2020, 11, 100465. [CrossRef]

17. Li, H.; Lu, J.; Zhang, Y.; Liu, Z. Hydrothermal Liquefaction of Typical Livestock Manures in China: Biocrude oil Production and Migration of Heavy Metals. J. Anal. Appl. Pyrolysis 2018, 135, 133-140. [CrossRef]

18. De Caprariis, B.; De Filippis, P.; Petrullo, A.; Scarsella, M. Hydrothermal liquefaction of biomass: Influence of temperature and biomass composition on the bio-oil production. Fuel 2017, 208, 618-625. [CrossRef]

19. Mathanker, A.; Pudasainee, D.; Kumar, A.; Gupta, R. Hydrothermal liquefaction of lignocellulosic biomass feedstock to produce biofuels: Parametric study and products characterization. Fuel 2020, 271, 117534. [CrossRef]

20. Tian, Y.; Wang, F.; Djandja, J.O.; Zhang, S.L.; Xu, Y.P.; Duan, P.G. Hydrothermal liquefaction of crop straws: Effect of feedstock composition. Fuel 2020, 265, 116946. [CrossRef]

21. Khan, N.; Chowdhary, P.; Ahmad, A.; Shekher Giri, B.; Chaturvedi, P. Hydrothermal liquefaction of rice husk and cow dung in Mixed-Bed-Rotating Pyrolyzer and application of biochar for dye removal. Bioresour. Technol. 2020, 309, 123294. [CrossRef]

22. Shahi, T.; Beheshti, B.; Zenouzi, A.; Almasi, M. Bio-oil production from residual biomass of microalgae after lipid extraction: The case of Dunaliella sp. Biocatal. Agric. Biotechnol. 2020, 23, 101494. [CrossRef]

23. Wu, X.F.; Zhang, J.J.; Huang, Y.H.; Li, M.F.; Bian, J.; Peng, F. Comparative investigation on bio-oil production from eucalyptus via liquefaction in subcritical water and supercritical ethanol. Ind. Crops Prod. 2019, 140, 111695. [CrossRef]

24. Fernandes, F.; Matos, S.; Gaspar, D.; Silva, L.; Paulo, I.; Vieira, S.; Pinto, P.C.R.; Bordado, J.; dos Santos, R.G. Boosting the higher heating value of Eucalyptus globulus via thermochemical liquefaction. Sustainability 2021, 13, 3717. [CrossRef]

25. Dhanavath, K.N.; Islam, M.S.; Bankupalli, S.; Bhargava, S.K.; Shah, K.; Parthasarathy, R. Experimental investigations on the effect of pyrolytic bio-oil during the liquefaction of Karanja Press Seed Cake. J. Environ. Chem. Eng. 2017, 5, 4986-4993. [CrossRef]

26. Zhang, B.; Chen, J.; Kandasamy, S.; He, Z. Hydrothermal liquefaction of fresh lemon-peel and Spirulina platensis blendingoperation parameter and biocrude chemistry investigation. Energy 2020, 193, 116645. [CrossRef]

27. Yang, T.; Wu, K.; Li, B.; Du, C.; Wang, J.; Li, R. Conversion of lignin into phenolic-rich oil by two-step liquefaction in subsupercritical ethanol system assisted by carbon dioxide. J. Energy Inst. 2021, 94, 329-336. [CrossRef]

28. Anastasakis, K.; Biller, P.; Madsen, R.B.; Glasius, M.; Johannsen, I. Continuous Hydrothermal Liquefaction of Biomass in a Novel Pilot Plant with Heat Recovery and Hydraulic Oscillation. Energies 2018, 11, 2695. [CrossRef]

29. Devi, T.E.; Parthiban, R. Hydrothermal liquefaction of Nostoc ellipsosporum biomass grown in municipal wastewater under optimized conditions for bio-oil production. Bioresour. Technol. 2020, 316, 123943. [CrossRef]

30. Chan, Y.H.; Quitain, A.T.; Yusup, S.; Uemura, Y.; Sasaki, M.; Kida, T. Liquefaction of palm kernel shell in sub- and supercritical water for bio-oil production. J. Energy Inst. 2018, 91, 721-732. [CrossRef]

31. Amado, M.; Bastos, D.; Gaspar, D.; Matos, S.; Vieira, S.; Bordado, J.M.; Galhano dos Santos, R. Thermochemical liquefaction of pinewood shaves-Evaluating the performance of cleaner and sustainable alternative solvents. J. Clean. Prod. $2021,304$. [CrossRef]

32. Wu, X.F.; Zhou, Q.; Li, M.F.; Li, S.X.; Bian, J.; Peng, F. Conversion of poplar into bio-oil via subcritical hydrothermal liquefaction: Structure and antioxidant capacity. Bioresour. Technol. 2018, 270, 216-222. [CrossRef] [PubMed]

33. Galhano dos Santos, R.; Ventura, P.; Bordado, J.C.; Mateus, M.M. Direct and efficient liquefaction of potato peel into bio-oil. Environ. Chem. Lett. 2017, 15, 453-458. [CrossRef]

34. Paul, T.; Sinharoy, A.; Pakshirajan, K.; Pugazhenthi, G. Lipid-rich bacterial biomass production using refinery wastewater in a bubble column bioreactor for bio-oil conversion by hydrothermal liquefaction. J. Water Process Eng. 2020, 37, 101462. [CrossRef]

35. Chen, D.; Ma, Q.; Wei, L.; Li, N.; Shen, Q.; Tian, W.; Zhou, J.; Long, J. Catalytic hydroliquefaction of rice straw for bio-oil production using $\mathrm{Ni} / \mathrm{CeO}_{2}$ catalysts. J. Anal. Appl. Pyrolysis 2018, 130, 249-255. [CrossRef]

36. Ma, Q.; Chen, D.; Wei, L.; Shen, Q.; Ji, Z.; Chen, Y.; Zou, X.; Xu, C.; Zhou, J. Bio-oil production from hydrogenation liquefaction of rice straw over metal $(\mathrm{Ni}, \mathrm{Co}, \mathrm{Cu})$-modified $\mathrm{CeO}_{2}$ catalysts. Energy Sources Part A Recover. Util. Environ. Eff. 2018, 40, 200-206. [CrossRef]

37. Leng, L.; Li, J.; Yuan, X.; Li, J.; Han, P.; Hong, Y.; Wei, F.; Zhou, W. Beneficial synergistic effect on bio-oil production from co-liquefaction of sewage sludge and lignocellulosic biomass. Bioresour. Technol. 2018, 251, 49-56. [CrossRef]

38. Arun, J.; Gopinath, K.P.; SundarRajan, P.S.; Malolan, R.; Adithya, S.; Sai Jayaraman, R.; Srinivaasan Ajay, P. Hydrothermal liquefaction of Scenedesmus obliquus using a novel catalyst derived from clam shells: Solid residue as catalyst for hydrogen production. Bioresour. Technol. 2020, 310, 123443. [CrossRef] 
39. Xu, Y.; Hu, Y.; Peng, Y.; Yao, L.; Dong, Y.; Yang, B.; Song, R. Catalytic pyrolysis and liquefaction behavior of microalgae for bio-oil production. Bioresour. Technol. 2020, 300, 122665. [CrossRef]

40. Zhang, B.; Feng, H.; He, Z.; Wang, S.; Chen, H. Bio-oil production from hydrothermal liquefaction of ultrasonic pre-treated Spirulina platensis. Energy Convers. Manag. 2018, 159, 204-212. [CrossRef]

41. Amarasekara, A.S.; Deng, F. Acidic ionic liquid catalyzed liquefaction of untreated switchgrass biomass in acetone and Pd$\mathrm{La}(\mathrm{OTf})_{3}$ catalyzed reduction of the products. Biomass Bioenergy 2019, 127, 105260. [CrossRef]

42. Ahmed, A.; Abu Bakar, M.S.; Azad, A.K.; Sukri, R.S.; Phusunti, N. Intermediate pyrolysis of Acacia cincinnata and Acacia holosericea species for bio-oil and biochar production. Energy Convers. Manag. 2018, 176, 393-408. [CrossRef]

43. Charusiri, W.; Numcharoenpinij, N. Characterization of the optimal catalytic pyrolysis conditions for bio-oil production from brown salwood (Acacia mangium Willd) residues. Biomass Bioenergy 2017, 106, 127-136. [CrossRef]

44. Ahmed, A.; Abu Bakar, M.S.; Sukri, R.S.; Hussain, M.; Farooq, A.; Moogi, S.; Park, Y.K. Sawdust pyrolysis from the furniture industry in an auger pyrolysis reactor system for biochar and bio-oil production. Energy Convers. Manag. 2020, $226,113502$. [CrossRef]

45. Gautam, N.; Chaurasia, A. Study on kinetics and bio-oil production from rice husk, rice straw, bamboo, sugarcane bagasse and neem bark in a fixed-bed pyrolysis process. Energy 2020, 190, 116434. [CrossRef]

46. Khuenkaeo, N.; Tippayawong, N. Production and characterization of bio-oil and biochar from ablative pyrolysis of lignocellulosic biomass residues. Chem. Eng. Commun. 2020, 207, 153-160. [CrossRef]

47. Gonçalves, G.D.C.; Nakamura, P.K.; Furtado, D.F.; Veit, M.T. Utilization of brewery residues to produces granular activated carbon and bio-oil. J. Clean. Prod. 2017, 168, 908-916. [CrossRef]

48. Wang, Y.; Zeng, Z.; Tian, X.; Dai, L.; Jiang, L.; Zhang, S.; Wu, Q.; Wen, P.; Fu, G.; Liu, Y.; et al. Production of bio-oil from agricultural waste by using a continuous fast microwave pyrolysis system. Bioresour. Technol. 2018, 269, 162-168. [CrossRef] [PubMed]

49. Lazzari, E.; Schena, T.; Marcelo, M.C.A.; Primaz, C.T.; Silva, A.N.; Ferrão, M.F.; Bjerk, T.; Caramão, E.B. Classification of biomass through their pyrolytic bio-oil composition using FTIR and PCA analysis. Ind. Crops Prod. 2018, 111, 856-864. [CrossRef]

50. Ansari, K.B.; Arora, J.S.; Chew, J.W.; Dauenhauer, P.J.; Mushrif, S.H. Fast Pyrolysis of Cellulose, Hemicellulose, and Lignin: Effect of Operating Temperature on Bio-oil Yield and Composition and Insights into the Intrinsic Pyrolysis Chemistry. Ind. Eng. Chem. Res. 2019, 58, 15838-15852. [CrossRef]

51. Zainan, N.H.; Srivatsa, S.C.; Li, F.; Bhattacharya, S. Quality of bio-oil from catalytic pyrolysis of microalgae Chlorella vulgaris. Fuel 2018, 223, 12-19. [CrossRef]

52. Adamakis, I.D.; Lazaridis, P.A.; Terzopoulou, E.; Torofias, S.; Valari, M.; Kalaitzi, P.; Rousonikolos, V.; Gkoutzikostas, D.; Zouboulis, A.; Zalidis, G.; et al. Cultivation, characterization, and properties of Chlorella vulgaris microalgae with different lipid contents and effect on fast pyrolysis oil composition. Environ. Sci. Pollut. Res. 2018, 25, 23018-23032. [CrossRef] [PubMed]

53. Sotoudehnia, F.; Baba Rabiu, A.; Alayat, A.; McDonald, A.G. Characterization of bio-oil and biochar from pyrolysis of waste corrugated cardboard. J. Anal. Appl. Pyrolysis 2020, 145, 104722. [CrossRef]

54. Primaz, C.T.; Ribes-Greus, A.; Jacques, R.A. Valorization of cotton residues for production of bio-oil and engineered biochar. Energy 2021, 235, 121363. [CrossRef]

55. Chen, X.; Chen, Y.; Yang, H.; Wang, X.; Che, Q.; Chen, W.; Chen, H. Catalytic fast pyrolysis of biomass: Selective deoxygenation to balance the quality and yield of bio-oil. Bioresour. Technol. 2019, 273, 153-158. [CrossRef] [PubMed]

56. Cheng, S.; Shu, J.; Xia, H.; Wang, S.; Zhang, L.; Peng, J.; Li, C.; Jiang, X.; Zhang, Q. Pyrolysis of Crofton weed for the production of aldehyde rich bio-oil and combustible matter rich bio-gas. Appl. Therm. Eng. 2019, 148, 1164-1170. [CrossRef]

57. Cao, B.; Wang, S.; Hu, Y.; Abomohra, A.E.F.; Qian, L.; He, Z.; Wang, Q.; Uzoejinwa, B.B.; Esakkimuthu, S. Effect of washing with diluted acids on Enteromorpha clathrata pyrolysis products: Towards enhanced bio-oil from seaweeds. Renew. Energy 2019, 138, 29-38. [CrossRef]

58. Chireshe, F.; Collard, F.X.; Görgens, J.F. Production of low oxygen bio-oil via catalytic pyrolysis of forest residues in a kilogramscale rotary kiln reactor. J. Clean. Prod. 2020, 260, 120987. [CrossRef]

59. Amin, M.; Chetpattananondh, P.; Ratanawilai, S. Application of extracted marine Chlorella sp. residue for bio-oil production as the biomass feedstock and microwave absorber. Energy Convers. Manag. 2019, 195, 819-829. [CrossRef]

60. Kadlimatti, H.M.; Raj Mohan, B.; Saidutta, M.B. Bio-oil from microwave assisted pyrolysis of food waste-optimization using response surface methodology. Biomass Bioenergy 2019, 123, 25-33. [CrossRef]

61. Van Schalkwyk, D.L.; Mandegari, M.; Farzad, S.; Görgens, J.F. Techno-economic and environmental analysis of bio-oil production from forest residues via non-catalytic and catalytic pyrolysis processes. Energy Convers. Manag. 2020, 213, 112815. [CrossRef]

62. Park, J.Y.; Kim, J.K.; Oh, C.H.; Park, J.W.; Kwon, E.E. Production of bio-oil from fast pyrolysis of biomass using a pilot-scale circulating fluidized bed reactor and its characterization. J. Environ. Manage. 2019, 234, 138-144. [CrossRef] [PubMed]

63. Papari, S.; Hawboldt, K.; Helleur, R. Production and Characterization of Pyrolysis Oil from Sawmill Residues in an Auger Reactor. Ind. Eng. Chem. Res. 2017, 56, 1920-1925. [CrossRef]

64. Hidayat, S.; Abu Bakar, M.S.; Yang, Y.; Phusunti, N.; Bridgwater, A.V. Characterisation and Py-GC/MS analysis of Imperata Cylindrica as potential biomass for bio-oil production in Brunei Darussalam. J. Anal. Appl. Pyrolysis 2018, 134, 510-519. [CrossRef]

65. Yücedağ, E.; Durak, H. Bio-oil and bio-char from lactuca scariola: Significance of catalyst and temperature for assessing yield and quality of pyrolysis. Energy Sources Part A Recover. Util. Environ. Eff. 2019, 1-14. [CrossRef] 
66. Wang, W.; Li, X.; Ye, D.; Cai, L.P.; Shi, S.Q. Catalytic pyrolysis of larch sawdust for phenol-rich bio-oil using different catalysts. Renew. Energy 2018, 121, 146-152. [CrossRef]

67. Abu Bakar, M.S.; Ahmed, A.; Jeffery, D.M.; Hidayat, S.; Sukri, R.S.; Mahlia, T.M.I.; Jamil, F.; Khurrum, M.S.; Inayat, A.; Moogi, S.; et al. Pyrolysis of solid waste residues from Lemon Myrtle essential oils extraction for bio-oil production. Bioresour. Technol. 2020 318, 123913. [CrossRef] [PubMed]

68. Zadeh, Z.E.; Abdulkhani, A.; Saha, B. Characterization of fast pyrolysis bio-oil from hardwood and softwood lignin. Energies 2020, 13, 887. [CrossRef]

69. Pradhan, D.; Bendu, H.; Singh, R.K.; Murugan, S. Mahua seed pyrolysis oil blends as an alternative fuel for light-duty diesel engines. Energy 2017, 118, 600-612. [CrossRef]

70. Dong, Q.; Li, H.; Niu, M.; Luo, C.; Zhang, J.; Qi, B.; Li, X.; Zhong, W. Microwave pyrolysis of moso bamboo for syngas production and bio-oil upgrading over bamboo-based biochar catalyst. Bioresour. Technol. 2018, 266, 284-290. [CrossRef]

71. Yang, Y.; Zhang, Y.; Omairey, E.; Cai, J.; Gu, F.; Bridgwater, A.V. Intermediate pyrolysis of organic fraction of municipal solid waste and rheological study of the pyrolysis oil for potential use as bio-bitumen. J. Clean. Prod. 2018, 187, 390-399. [CrossRef]

72. Suntivarakorn, R.; Treedet, W.; Singbua, P.; Teeramaetawat, N. Fast pyrolysis from Napier grass for pyrolysis oil production by using circulating Fluidized Bed Reactor: Improvement of pyrolysis system and production cost. Energy Rep. 2018, 4, 565-575. [CrossRef]

73. Lin, B.; Huang, Q.; Chi, Y. Co-pyrolysis of oily sludge and rice husk for improving pyrolysis oil quality. Fuel Process. Technol. 2018, 177, 275-282. [CrossRef]

74. Kostas, E.T.; Durán-Jiménez, G.; Shepherd, B.J.; Meredith, W.; Stevens, L.A.; Williams, O.S.A.; Lye, G.J.; Robinson, J.P. Microwave pyrolysis of olive pomace for bio-oil and bio-char production. Chem. Eng. J. 2020, 387, 123404. [CrossRef]

75. Bartoli, M.; Rosi, L.; Giovannelli, A.; Frediani, P.; Frediani, M. Characterization of bio-oil and bio-char produced by lowtemperature microwave-assisted pyrolysis of olive pruning residue using various absorbers. Waste Manag. Res. 2020, 38, 213-225. [CrossRef]

76. Moutsoglou, A.; Lawburgh, B.; Lawburgh, J. Fractional condensation and aging of pyrolysis oil from softwood and organosolv lignin. J. Anal. Appl. Pyrolysis 2018, 135, 350-360. [CrossRef]

77. Park, J.W.; Heo, J.; Ly, H.V.; Kim, J.; Lim, H.; Kim, S.S. Fast pyrolysis of acid-washed oil palm empty fruit bunch for bio-oil production in a bubbling fluidized-bed reactor. Energy 2019, 179, 517-527. [CrossRef]

78. Idris, R.; Chong, W.W.F.; Ali, A.; Idris, S.; Hasan, M.F.; Ani, F.N.; Chong, C.T. Phenol-rich bio-oil derivation via microwave-induced fast pyrolysis of oil palm empty fruit bunch with activated carbon. Environ. Technol. Innov. 2021, 21, 101291. [CrossRef]

79. Vasu, H.; Wong, C.F.; Vijiaretnam, N.R.; Chong, Y.Y.; Thangalazhy-Gopakumar, S.; Gan, S.; Lee, L.Y.; Ng, H.K. Insight into Co-pyrolysis of Palm Kernel Shell (PKS) with Palm Oil Sludge (POS): Effect on Bio-oil Yield and Properties. Waste Biomass Valorization 2020, 11, 5877-5889. [CrossRef]

80. Qureshi, K.M.; Lup, A.N.K.; Khan, S.; Abnisa, F.; Daud, W.M.A.W. Effect of temperature and feed rate on pyrolysis oil produced via helical screw fluidized bed reactor. Korean J. Chem. Eng. 2021, 38, 1797-1809. [CrossRef]

81. Edmunds, C.W.; Molina, E.A.R.; André, N.; Hamilton, C.; Park, S.; Fasina, O.; Adhikari, S.; Kelley, S.S.; Tumuluru, J.S.; Rials, T.G.; et al. Blended feedstocks for thermochemical conversion: Biomass characterization and bio-oil production from switchgrass-pine residues blends. Front. Energy Res. 2018, 6, 1-16. [CrossRef]

82. Gupta, S.; Lanjewar, R.; Mondal, P. Enhancement of hydrocarbons and phenols in catalytic pyrolysis bio-oil by employing aluminum hydroxide nanoparticle based spent adsorbent derived catalysts. Chemosphere 2022, 287, 132220. [CrossRef] [PubMed]

83. Alvarez, J.; Amutio, M.; Lopez, G.; Santamaria, L.; Bilbao, J.; Olazar, M. Improving bio-oil properties through the fast co-pyrolysis of lignocellulosic biomass and waste tyres. Waste Manag. 2019, 85, 385-395. [CrossRef] [PubMed]

84. Echresh Zadeh, Z.; Abdulkhani, A.; Saha, B. A comparative production and characterisation of fast pyrolysis bio-oil from Populus and Spruce woods. Energy 2021, 214, 118930. [CrossRef]

85. Maisano, S.; Urbani, F.; Mondello, N.; Chiodo, V. Catalytic pyrolysis of Mediterranean sea plant for bio-oil production. Int. J. Hydrog. Energy 2017, 42, 28082-28092. [CrossRef]

86. Tshikesho, R.S.; Kumar, A.; Huhnke, R.L.; Apblett, A. Catalytic co-pyrolysis of red cedar with methane to produce upgraded bio-oil. Bioresour. Technol. 2019, 285, 121299. [CrossRef]

87. Lazzari, E.; dos Santos Polidoro, A.; Onorevoli, B.; Schena, T.; Silva, A.N.; Scapin, E.; Jacques, R.A.; Caramão, E.B. Production of rice husk bio-oil and comprehensive characterization (qualitative and quantitative) by HPLC/PDA and GC $\times$ GC/qMS. Renew. Energy 2019, 135, 554-565. [CrossRef]

88. Cai, W.; Dai, L.; Liu, R. Catalytic fast pyrolysis of rice husk for bio-oil production. Energy 2018, 154, 477-487. [CrossRef]

89. Cai, W.; Liu, R.; He, Y.; Chai, M.; Cai, J. Bio-oil production from fast pyrolysis of rice husk in a commercial-scale plant with a downdraft circulating fluidized bed reactor. Fuel Process. Technol. 2018, 171, 308-317. [CrossRef]

90. Ma, S.; Zhang, L.; Zhu, L.; Zhu, X. Preparation of multipurpose bio-oil from rice husk by pyrolysis and fractional condensation. J. Anal. Appl. Pyrolysis 2018, 131, 113-119. [CrossRef]

91. Sahoo, K.; Kumar, A.; Chakraborty, J.P. A comparative study on valuable products: Bio-oil, biochar, non-condensable gases from pyrolysis of agricultural residues. J. Mater. Cycles Waste Manag. 2021, 23, 186-204. [CrossRef] 
92. Liang, J.; Morgan, H.M.; Liu, Y.; Shi, A.; Lei, H.; Mao, H.; Bu, Q. Enhancement of bio-oil yield and selectivity and kinetic study of catalytic pyrolysis of rice straw over transition metal modified ZSM-5 catalyst. J. Anal. Appl. Pyrolysis 2017, 128, 324-334. [CrossRef]

93. Ahmed, N.; Zeeshan, M.; Iqbal, N.; Farooq, M.Z.; Shah, S.A. Investigation on bio-oil yield and quality with scrap tire addition in sugarcane bagasse pyrolysis. J. Clean. Prod. 2018, 196, 927-934. [CrossRef]

94. Chorazy, T.; Čáslavský, J.; Žvaková, V.; Raček, J.; Hlavínek, P. Characteristics of Pyrolysis Oil as Renewable Source of Chemical Materials and Alternative Fuel from the Sewage Sludge Treatment. Waste Biomass Valorization 2020, 11, 4491-4505. [CrossRef]

95. Laesecke, J.; Ellis, N.; Kirchen, P. Production, analysis and combustion characterization of biomass fast pyrolysis oil—Biodiesel blends for use in diesel engines. Fuel 2017, 199, 346-357. [CrossRef]

96. Teixeira Cardoso, A.R.; Conrado, N.M.; Krause, M.C.; Bjerk, T.R.; Krause, L.C.; Caramão, E.B. Chemical characterization of the bio-oil obtained by catalytic pyrolysis of sugarcane bagasse (industrial waste) from the species Erianthus arundinaceus. J. Environ. Chem. Eng. 2019, 7, 102970. [CrossRef]

97. Sukumar, V.; Manieniyan, V.; Senthilkumar, R.; Sivaprakasam, S. Production of bio oil from sweet lime empty fruit bunch by pyrolysis. Renew. Energy 2020, 146, 309-315. [CrossRef]

98. Chen, D.; Gao, D.; Capareda, S.C.; Huang, S.; Wang, Y. Effects of hydrochloric acid washing on the microstructure and pyrolysis bio-oil components of sweet sorghum bagasse. Bioresour. Technol. 2019, 277, 37-45. [CrossRef]

99. Yan, B.; Zhang, S.; Chen, W.; Cai, Q. Pyrolysis of tobacco wastes for bio-oil with aroma compounds. J. Anal. Appl. Pyrolysis 2018, 248-254. [CrossRef]

100. Midhun Prasad, K.; Murugavelh, S. Experimental investigation and kinetics of tomato peel pyrolysis: Performance, combustion and emission characteristics of bio-oil blends in diesel engine. J. Clean. Prod. 2020, 254, 120115. [CrossRef]

101. Ly, H.V.; Lim, D.H.; Sim, J.W.; Kim, S.S.; Kim, J. Catalytic pyrolysis of tulip tree (Liriodendron) in bubbling fluidized-bed reactor for upgrading bio-oil using dolomite catalyst. Energy 2018, 162, 564-575. [CrossRef]

102. Wu, Q.; Wang, Y.; Peng, Y.; Ke, L.; Yang, Q.; Jiang, L.; Dai, L.; Liu, Y.; Ruan, R.; Xia, D.; et al. Microwave-assisted pyrolysis of waste cooking oil for hydrocarbon bio-oil over metal oxides and HZSM-5 catalysts. Energy Convers. Manag. 2020, $220,113124$. [CrossRef]

103. Iqbal, T.; Lu, Q.; Dong, C.Q.; Zhou, M.X.; Arain, Z.; Ali, Z.; Khan, I.; Hussain, Z.; Abbas, A. A study of product distribution under fast pyrolysis of wheat stalk while producing bio-oil. 2018 Int. Conf. Comput. Math. Eng. Technol. Inven. Innov. Integr. Socioecon. Dev. iCoMET 2018 - Proc. 2018, 2018, 1-6. [CrossRef]

104. Eschenbacher, A.; Saraeian, A.; Shanks, B.H.; Jensen, P.A.; Li, C.; Duus, J.Ø.; Hansen, A.B.; Mentzel, U.V.; Henriksen, U.B.; Ahrenfeldt, J.; et al. Enhancing bio-oil quality and energy recovery by atmospheric hydrodeoxygenation of wheat straw pyrolysis vapors using Pt and Mo-based catalysts. Sustain. Energy Fuels 2020, 4, 1991-2008. [CrossRef]

105. Paul, A.S.; Panwar, N.L.; Salvi, B.L.; Jain, S.; Sharma, D. Experimental investigation on the production of bio-oil from wheat straw. Energy Sources Part A Recover. Util. Environ. Eff. 2020, 1-16. [CrossRef]

106. dos Santos Polidoro, A.; Scapin, E.; Lazzari, E.; Silva, A.N.; dos Santos, A.L.; Caramão, E.B.; Jacques, R.A. Valorization of coffee silverskin industrial waste by pyrolysis: From optimization of bio-oil production to chemical characterization by GC $\times$ GC/qMS. J. Anal. Appl. Pyrolysis 2018, 129, 43-52. [CrossRef]

107. Aboulkas, A.; Hammani, H.; El Achaby, M.; Bilal, E.; Barakat, A.; El harfi, K. Valorization of algal waste via pyrolysis in a fixed-bed reactor: Production and characterization of bio-oil and bio-char. Bioresour. Technol. 2017, 243, 400-408. [CrossRef]

108. Kumar, R.; Strezov, V. Thermochemical production of bio-oil: A review of downstream processing technologies for bio-oil upgrading, production of hydrogen and high value-added products. Renew. Sustain. Energy Rev. 2021, 135, 110152. [CrossRef]

109. Li, J.; Chen, Y.; Yang, H.; Zhu, D.; Chen, X.; Wang, X.; Chen, H. Correlation of Feedstock and Bio-oil Compound Distribution. Energy Fuels 2017, 31, 7093-7100. [CrossRef]

110. Fan, Y.; Cai, Y.; Li, X.; Jiao, L.; Xia, J.; Deng, X. Effects of the cellulose, xylan and lignin constituents on biomass pyrolysis characteristics and bio-oil composition using the Simplex Lattice Mixture Design method. Energy Convers. Manag. 2017, 138, 106-118. [CrossRef]

111. Tang, Q.; Chen, Y.; Yang, H.; Liu, M.; Xiao, H.; Wu, Z.; Chen, H.; Naqvi, S.R. Prediction of Bio-oil Yield and Hydrogen Contents Based on Machine Learning Method: Effect of Biomass Compositions and Pyrolysis Conditions. Energy Fuels 2020, 34, 11050-11060. [CrossRef]

112. Auersvald, M.; Macek, T.; Schulzke, T.; Staš, M.; Šimáček, P. Influence of biomass type on the composition of bio-oils from ablative fast pyrolysis. J. Anal. Appl. Pyrolysis 2020, 150, 104838. [CrossRef]

113. Abdul Latif, N.I.S.; Ong, M.Y.; Nomanbhay, S. Hydrothermal liquefaction of Malaysia's algal biomass for high-quality bio-oil production. Eng. Life Sci. 2019, 19, 246-269. [CrossRef] [PubMed]

114. Wei, L.; Liang, S.; Guho, N.M.; Hanson, A.J.; Smith, M.W.; Garcia-Perez, M.; McDonald, A.G. Production and characterization of bio-oil and biochar from the pyrolysis of residual bacterial biomass from a polyhydroxyalkanoate production process. J. Anal. Appl. Pyrolysis 2015, 115, 268-278. [CrossRef]

115. McIntosh, S.; Nabi, M.N.; Moghaddam, L.; Brooks, P.; Ghandehari, P.S.; Erler, D. Combined pyrolysis and sulphided $\mathrm{NiMo} / \mathrm{Al}_{2} \mathrm{O}_{3}$ catalysed hydroprocessing in a multistage strategy for the production of biofuels from milk processing waste. Fuel 2021, 295, 120602. [CrossRef] 
116. Kim, J.S. Production, separation and applications of phenolic-rich bio-oil-A review. Bioresour. Technol. 2015, 178, 90-98. [CrossRef]

117. Dai, L.; Zhou, N.; Li, H.; Deng, W.; Cheng, Y.; Wang, Y.; Liu, Y.; Cobb, K.; Lei, H.; Chen, P.; et al. Recent advances in improving lignocellulosic biomass-based bio-oil production. J. Anal. Appl. Pyrolysis 2020, 149, 104845. [CrossRef]

118. He, T.; Zhong, Z.; Zhang, B. Bio-oil Upgrading via Ether Extraction, Looped-Oxide Catalytic Deoxygenation, and Mild Electrocatalytic Hydrogenation Techniques. Energy Fuels 2020, 34, 9725-9733. [CrossRef]

119. Jacobson, K.; Maheria, K.C.; Kumar Dalai, A. Bio-oil valorization: A review. Renew. Sustain. Energy Rev. 2013, $23,91-106$. [CrossRef]

120. Elkasabi, Y.; Mullen, C.A.; Jackson, M.A.; Boateng, A.A. Characterization of fast-pyrolysis bio-oil distillation residues and their potential applications. J. Anal. Appl. Pyrolysis 2015, 114, 179-186. [CrossRef]

121. Chan, Y.H.; Yusup, S.; Quitain, A.T.; Uemura, Y.; Sasaki, M. Bio-oil production from oil palm biomass via subcritical and supercritical hydrothermal liquefaction. J. Supercrit. Fluids 2014, 95, 407-412. [CrossRef]

122. Cao, L.; Zhang, C.; Hao, S.; Luo, G.; Zhang, S.; Chen, J. Effect of glycerol as co-solvent on yields of bio-oil from rice straw through hydrothermal liquefaction. Bioresour. Technol. 2016, 220, 471-478. [CrossRef] [PubMed]

123. Vecino Mantilla, S.; Gauthier-Maradei, P.; Álvarez Gil, P.; Tarazona Cárdenas, S. Comparative study of bio-oil production from sugarcane bagasse and palm empty fruit bunch: Yield optimization and bio-oil characterization. J. Anal. Appl. Pyrolysis 2014, 108, 284-294. [CrossRef]

124. Choi, G.G.; Oh, S.J.; Lee, S.J.; Kim, J.S. Production of bio-based phenolic resin and activated carbon from bio-oil and biochar derived from fast pyrolysis of palm kernel shells. Bioresour. Technol. 2015, 178, 99-107. [CrossRef] [PubMed]

125. Omoriyekomwan, J.E.; Tahmasebi, A.; Yu, J. Production of phenol-rich bio-oil during catalytic fixed-bed and microwave pyrolysis of palm kernel shell. Bioresour. Technol. 2016, 207, 188-196. [CrossRef] [PubMed]

126. Abnisa, F.; Daud, W.M.A.W.; Husin, W.N.W.; Sahu, J.N. Utilization possibilities of palm shell as a source of biomass energy in Malaysia by producing bio-oil in pyrolysis process. Biomass Bioenergy 2011, 35, 1863-1872. [CrossRef]

127. Pinheiro Pires, A.P.; Arauzo, J.; Fonts, I.; Domine, M.E.; Fernández Arroyo, A.; Garcia-Perez, M.E.; Montoya, J.; Chejne, F.; Pfromm, P.; Garcia-Perez, M. Challenges and opportunities for bio-oil refining: A review. Energy Fuels 2019, 33, 4683-4720. [CrossRef]

128. Wang, C.; Luo, Z.; Li, S.; Zhu, X. Coupling effect of condensing temperature and residence time on bio-oil component enrichment during the condensation of biomass pyrolysis vapors. Fuel 2020, 274, 117861. [CrossRef]

129. Urrutia, R.I.; Yeguerman, C.; Jesser, E.; Gutierrez, V.S.; Volpe, M.A.; Werdin González, J.O. Sunflower seed hulls waste as a novel source of insecticidal product: Pyrolysis bio-oil bioactivity on insect pests of stored grains and products. J. Clean. Prod. 2021, 287, 125000. [CrossRef]

130. Sarchami, T.; Batta, N.; Berruti, F. Production and separation of acetic acid from pyrolysis oil of lignocellulosic biomass: A review. Biofuels Bioprod. Biorefining 2021, 15, 1912-1937. [CrossRef]

131. Luo, D.; Yin, W.; Han, D.; He, H.; Xia, S. Glycolic acid and formic acid production from pyrolysis oil water-soluble fraction by catalytic oxidation. Chem. Eng. Sci. 2021, 239, 116644. [CrossRef]

132. Sun, K.; Zhang, L.; Xu, Q.; Zhang, Z.; Shao, Y.; Dong, D.; Gao, G.; Liu, Q.; Wang, S.; Hu, X. Evidence for cross-polymerization between the biomass-derived furans and phenolics. Renew. Energy 2020, 154, 517-531. [CrossRef]

133. Sun, K.; Xu, Q.; Shao, Y.; Zhang, L.; Liu, Q.; Zhang, S.; Wang, Y.; Hu, X. Cross-Polymerization between the Typical Sugars and Phenolic Monomers in Bio-Oil: A Model Compounds Study. Energy Fuels 2019, 33, 7480-7490. [CrossRef]

134. Hu, X.; Nango, K.; Bao, L.; Li, T.; Mahmudul Hasan, M.D.; Li, C.Z. High yields of solid carbonaceous materials from biomass Green Chem. 2019, 21, 1128-1140. [CrossRef]

135. Cheng, S. Bio-Based Phenolic Resins and Adhesives Derived from Forestry Residues/Wastes and Lignin. Ph.D. Thesis, Lakehead University, Thunder Bay, ON, Canada, 2011. Available online: http://knowledgecommons.lakeheadu.ca/handle/2453/315 (accessed on 31 October 2021).

136. Yi, J.; Zhang, J.; Yao, S.; Chang, J.; Li, B. Preparation of bio-oil-phenol-formaldehyde resins from biomass pyrolysis oil. Appl. Mech. Mater. 2012, 174-177, 1429-1432. [CrossRef]

137. Vithanage, A.E.; Chowdhury, E.; Alejo, L.D.; Pomeroy, P.C.; DeSisto, W.J.; Frederick, B.G.; Gramlich, W.M. Renewably sourced phenolic resins from lignin bio-oil. J. Appl. Polym. Sci. 2017, 134, 1-10. [CrossRef]

138. Cui, Y.; Hou, X.; Wang, W.; Chang, J. Synthesis and characterization of bio-oil phenol formaldehyde resin used to fabricate phenolic based materials. Materials 2017, 10, 668. [CrossRef] [PubMed]

139. Celikbag, Y.; Nuruddin, M.; Biswas, M.; Asafu-Adjaye, O.; Via, B.K. Bio-oil-based phenol-formaldehyde resin: Comparison of weight- and molar-based substitution of phenol with bio-oil. J. Adhes. Sci. Technol. 2020, 34, 2743-2754. [CrossRef]

140. Sarika, P.R.; Nancarrow, P.; Khansaheb, A.; Ibrahim, T. Bio-Based Alternatives to Phenol and Formaldehyde for the Production of Resins. Polymers 2020, 12, 2237. [CrossRef]

141. Hu, S.; Luo, X.; Li, Y. Polyols and polyurethanes from the liquefaction of lignocellulosic biomass. ChemSusChem 2014, 7, 66-72. [CrossRef]

142. Yu, Y.; Wang, Y.; Xu, P.; Chang, J. Preparation and characterization of phenolic foam modified with bio-oil. Materials 2018, 11, 2228. [CrossRef]

143. Schulzke, T.; Iakovleva, A.; Cao, Q.; Conrad, S.; Zabelkin, S.; Grachev, A. Polyurethane foams produced from pyrolysis oilProduction and possible application. Biomass Bioenergy 2018, 115, 195-202. [CrossRef] 
144. Rasman, M.; Hassan, N.A.; Hainin, M.R.; Putra Jaya, R.; Haryati, Y.; Shukry, N.A.M.; Abdullah, M.E.; Kamaruddin, N.H.M. Engineering properties of bitumen modified with bio-oil. MATEC Web Conf. 2018, 250, 02003. [CrossRef]

145. Ingrassia, L.P.; Lu, X.; Ferrotti, G.; Canestrari, F. Chemical, morphological and rheological characterization of bitumen partially replaced with wood bio-oil: Towards more sustainable materials in road pavements. J. Traffic Transp. Eng. 2020, 7, 192-204. [CrossRef]

146. Zhang, R.; You, Z.; Wang, H.; Ye, M.; Yap, Y.K.; Si, C. The impact of bio-oil as rejuvenator for aged asphalt binder. Constr. Build. Mater. 2019, 196, 134-143. [CrossRef]

147. Li, C.; Rajib, A.; Sarker, M.; Liu, R.; Fini, E.H.; Cai, J. Balancing the Aromatic and Ketone Content of Bio-Oils as Rejuvenators to Enhance Their Efficacy in Restoring Properties of Aged Bitumen. ACS Sustain. Chem. Eng. 2021, 9, 6912-6922. [CrossRef]

148. Poh, C.C.; Hassan, N.A.; Raman, N.A.A.; Shukry, N.A.M.; Warid, M.N.M.; Satar, M.K.I.M.; Ismail, C.R.; Hassan, S.A.; Mashros, N. Effect of fast pyrolysis bio-oil from palm oil empty fruit bunch on bitumen properties. IOP Conf. Ser. Mater. Sci. Eng. 2018, 342, 012053. [CrossRef]

149. Zabelkin, S.; Bikbulatova, G.; Grachev, A.; Bashkirov, V.; Burenkov, S.; Makarov, A. Modification of bitumen binder by the liquid products of wood fast pyrolysis. Road Mater. Pavement Des. 2019, 20, 1182-1200. [CrossRef]

150. Yang, H.M.; Zhao, W.; Norinaga, K.; Fang, J.J.; Wang, Y.G.; Zong, Z.M.; Wei, X.Y. Separation of phenols and ketones from bio-oil produced from ethanolysis of wheat stalk. Sep. Purif. Technol. 2015, 152, 238-245. [CrossRef]

151. Chan, Y.H.; Loh, S.K.; Chin, B.L.F.; Yiin, C.L.; How, B.S.; Cheah, K.W.; Wong, M.K.; Loy, A.C.M.; Gwee, Y.L.; Lo, S.L.Y.; et al. Fractionation and extraction of bio-oil for production of greener fuel and value-added chemicals: Recent advances and future prospects. Chem. Eng. J. 2020, 397, 125406. [CrossRef]

152. Stanford, J.P.; Hall, P.H.; Rover, M.R.; Smith, R.G.; Brown, R.C. Separation of sugars and phenolics from the heavy fraction of bio-oil using polymeric resin adsorbents. Sep. Purif. Technol. 2018, 194, 170-180. [CrossRef]

153. Wang, Y.; Han, Y.; Hu, W.; Fu, D.; Wang, G. Analytical strategies for chemical characterization of bio-oil. J. Sep. Sci. 2020, 43, 360-371. [CrossRef] [PubMed]

154. Michailof, C.M.; Kalogiannis, K.G.; Sfetsas, T.; Patiaka, D.T.; Lappas, A.A. Advanced analytical techniques for bio-oil characterization. Wiley Interdiscip. Rev. Energy Environ. 2016, 5, 614-639. [CrossRef]

155. Ohra-aho, T.; Rohrbach, L.; Winkelman, J.G.M.; Heeres, H.J.; Mikkelson, A.; Oasmaa, A.; van de Beld, B.; Leijenhorst, E.J.; Heeres, H. Evaluation of Analysis Methods for Formaldehyde, Acetaldehyde, and Furfural from Fast Pyrolysis Bio-Oil. Energy Fuels 2021, 35, 18583-18591. [CrossRef] [PubMed]

156. Lienemann, C.-P.; Quignard, A.; Texier, N.; Charon, N. Measuring inorganics in biomass fast pyrolysis oils. J. Anal. Appl. Pyrolysis 2021, 159, 105313. [CrossRef]

157. Kumar, R.; Strezov, V.; Weldekidan, H.; He, J.; Singh, S.; Kan, T.; Dastjerdi, B. Lignocellulose biomass pyrolysis for bio-oil production: A review of biomass pre-treatment methods for production of drop-in fuels. Renew. Sustain. Energy Rev. 2020, 123, 109763. [CrossRef]

158. Alvarez-Chavez, B.J.; Godbout, S.; Palacios-Rios, J.H.; Le Roux, É.; Raghavan, V. Physical, chemical, thermal and biological pre-treatment technologies in fast pyrolysis to maximize bio-oil quality: A critical review. Biomass Bioenergy 2019, $128,105333$. [CrossRef]

159. Tarves, P.C.; Serapiglia, M.J.; Mullen, C.A.; Boateng, A.A.; Volk, T.A. Effects of hot water extraction pretreatment on pyrolysis of shrub willow. Biomass Bioenergy 2017, 107, 299-304. [CrossRef]

160. Zhao, Q.; Mäkinen, M.; Haapala, A.; Jänis, J. Valorization of Bark from Short Rotation Trees by Temperature-Programmed Slow Pyrolysis. ACS Omega 2021, 6, 9771-9779. [CrossRef]

161. Xu, J.; Brodu, N.; Abdelouahed, L.; Taouk, B. Investigation of the combination of fractional condensation and water extraction for improving the storage stability of pyrolysis bio-oil. Fuel 2022, 314, 123019. [CrossRef]

162. Xu, J.; Brodu, N.; Wang, J.; Abdelouahed, L.; Taouk, B. Chemical characteristics of bio-oil from beech wood pyrolysis separated by fractional condensation and water extraction. J. Energy Inst. 2021, 99, 186-197. [CrossRef]

163. Albrecht, K.O.; Olarte, M.V.; Wang, H. Upgrading Fast Pyrolysis Liquids. In Thermochemical Processing of Biomass: Conversion into Fuels, Chemicals and Power; John Wiley \& Sons: Hoboken, NJ, USA, 2019; pp. 207-255.

164. Schulzke, T.; Conrad, S.; Westermeyer, J. Fractionation of flash pyrolysis condensates by staged condensation. Biomass Bioenergy 2016, 95, 287-295. [CrossRef]

165. Zhang, L.; Li, S.; Li, K.; Zhu, X. Two-step pyrolysis of corncob for value-added chemicals and high quality bio-oil: Effects of pyrolysis temperature and residence time. Energy Convers. Manag. 2018, 166, 260-267. [CrossRef]

166. Montesantos, N.; Pedersen, T.H.; Nielsen, R.P.; Rosendahl, L.; Maschietti, M. Supercritical carbon dioxide fractionation of bio-crude produced by hydrothermal liquefaction of pinewood. J. Supercrit. Fluids 2019, 149, 97-109. [CrossRef]

167. Feng, Y.; Meier, D. Supercritical carbon dioxide extraction of fast pyrolysis oil from softwood. J. Supercrit. Fluids 2017, 128, 6-17. [CrossRef]

168. Chan, Y.H.; Yusup, S.; Quitain, A.T.; Uemura, Y.; Loh, S.K. Fractionation of pyrolysis oil via supercritical carbon dioxide extraction: Optimization study using response surface methodology (RSM). Biomass Bioenergy 2017, 107, 155-163. [CrossRef]

169. Cesari, L.; Canabady-Rochelle, L.; Mutelet, F. Separation of phenols from lignin pyrolysis oil using ionic liquid. Sep. Purif. Technol. 2019, 209, 528-534. [CrossRef] 
170. Cristino, A.F.; Logan, D.; Bordado, J.C.; Dos Santos, R.G. The role of ionic liquids on biomass liquefaction-A short review of the recent advances. Processes 2021, 9, 1214. [CrossRef]

171. Hansen, S.; Mirkouei, A.; Diaz, L.A. A comprehensive state-of-technology review for upgrading bio-oil to renewable or blended hydrocarbon fuels. Renew. Sustain. Energy Rev. 2020, 118, 109548. [CrossRef]

172. Yuan, X.; Ding, X.; Leng, L.; Li, H.; Shao, J.; Qian, Y.; Huang, H.; Chen, X.; Zeng, G. Applications of bio-oil-based emulsions in a DI diesel engine: The effects of bio-oil compositions on engine performance and emissions. Energy 2018, 154, 110-118. [CrossRef]

173. Stefanidis, S.D.; Kalogiannis, K.G.; Lappas, A.A. Co-processing bio-oil in the refinery for drop-in biofuels via fluid catalytic cracking. Wiley Interdiscip. Rev. Energy Environ. 2018, 7, e281. [CrossRef]

174. Sharma, K.; Castello, D.; Haider, M.S.; Pedersen, T.H.; Rosendahl, L.A. Continuous co-processing of HTL bio-oil with renewable feed for drop-in biofuels production for sustainable refinery processes. Fuel 2021, 306, 121579. [CrossRef]

175. Wu, L.; Wang, Y.; Zheng, L.; Shi, M.; Li, J. Design and optimization of bio-oil co-processing with vacuum gas oil in a refinery. Energy Convers. Manag. 2019, 195, 620-629. [CrossRef]

176. Dimitriadis, A.; Liakos, D.; Pfisterer, U.; Moustaka-Gouni, M.; Karonis, D.; Bezergianni, S. Impact of hydrogenation on miscibility of fast pyrolysis bio-oil with refinery fractions towards bio-oil refinery integration. Biomass Bioenergy 2021, 151, 106171. [CrossRef] 